\title{
THE SACRED TOPOGRAPHY OF COLONIA SARMIZEGETUSA
}

\author{
IMOLA BODA \\ Babeș-Bolyai University of Cluj-Napoca \\ Mihail Kogălniceanu, nr. 1, Cluj-Napoca, RO-400084, Romania \\ boda_imola@yahoo.com
}

\begin{abstract}
The rituals carried out on the occasion of the establishment of a new Roman city prove the fact that there was a prescribed regulation. The location, orientation, as well as the scenography, translates into facts gestures and human processions with sacred character; these are the expression of a symbolic geography of religious type.

The erection of sacred buildings in Colonia Sarmizegetusa was carried out during the reign of Trajan (its founder) and Severus Alexander. For the following period (Maximinus-Aurelianus), the archaeological evidence suggests the fact that the emphasis was not placed on constructing new religious buildings, but on restoring the already existing ones. The expression of religious piety persisted, and one can make reference again to the archaeological evidence, more particular to shrines, and statues. This context proves the fact that the religious life continued its cycle. However, in AD 235, at the latest, Sarmizegetusa witnessed the construction of the most numerous temples. It is noteworthy to mention that this construction boom coincides with the period when Sarmizegetusa is granted the title of Metropolis.
\end{abstract}

Keywords: Roman Period, Roman religion, Colonia Sarmizegetusa, temple, sacred topography

Rite of foundation, setting up of the precinct, ceremonies occasioned by the establishment of a new Roman town, all indicate that the event was enacted according to a prescribed law- the activities known especially from literary sources. ${ }^{1}$ Owing to the extensive series of studies and monographs dedicated to this subject, today we have learnt the total procedure following the foundation of Roman cities.

The ritual starts with a contemplatio, i.e. observing the heavens and interpreting divine signs, after which the augur concludes on the appropriateness of the place selected for the establishment of the new town. ${ }^{2}$ This phase was followed by the proper founding ritual that commenced with a prayer and at the same time a vow to the gods, called supplicatio.

If the auspices had proved to be favourable, the ceremony of inauguratio have followed. This entailed the stages of orientatio, the alignment to the cardinal axes of the universe; then the augur determined the orientation of the four main sectors of the skies that would also be reflected on earth.

Afterwards sacrifices took place; these marked the deductio ceremony by which the now sacralised space of the new town was transferred into the possession of the gods.

${ }^{1}$ Regarding the analysis of literary sources, see the study of SANCTIS 2007, 503-526. For the rites of foundation, see NIESSEN 1906-1910. Concerning the mythical origins of Rome, see CORNEL 1999; CARANDINI-CAPELli 2000. With respect to the foundation of different towns, see AZARa-Mar-Subias 2001; Collart 1937.
${ }^{2}$ Vitruvius 1964 explains that at first and foremost it was checked whether there had been drinkable water at the site where the city was to be built. 
Finally, the apportion of the territory was effected. The land was measured and divided by the agrimensor ${ }^{3}$ into parcels (centuriae) which were allotted to the colonists.

The inference regarding the ceremony carried out when devising the enclosure of Colonia Sarmizegetusa, following the ancient custom of Gabii, is based on a coin dated to AD 112-116. On its obverse it features Trajan's bust seen from the profile, while on the reverse it depicts the emperor with the sulcus primigenius (a light plough, aratrum, at which an ox and a cow were yoked). The governor of Dacia, Decimus Terentius Scaurianus, drew the primordial furrow: he put on the toga and with his head covered as required by the ancient ritual, he executed the necessary procedure. The plough knife cut through the soil, marking the place of the defensive ditch, while the earth turned over by the ploughshare was to become the earthen rampart with palisade meant to protect the city. ${ }^{4}$

The depiction of the foundation scene is very often encountered on colonial coins. ${ }^{5}$ As an analogy we can foremost recall the foundation of the town of Philippi. Paul Collart worked out the following sequence: after the colonists' arrival and in case of favourable auspices, the founder put on the ritual toga and started drawing the precinct of the colonia with the help of an ox and a cow. These stages are confirmed by the numismatic evidence of the coins bearing the legend legatus coloniae deducendae. ${ }^{6}$

In Hispania, like in Sarmizegetusa and Philippi, the commemoration of the foundation of the colonies Celsa (Valle del Ebro), Augusta Emerita (Mérida) and Caesara Augusta (Zaragoza) is also confirmed by the numismatic evidence. Here the sacerdos represented on coins holds a staff in his left hand, while with the right he is ploughing the sulcus primigenius. ${ }^{7}$

Another analogy can be found on a relief from Aquileia (Italy) with the scene of the foundation of the city, again by drawing the sulcus primigenius. ${ }^{8}$

\section{MAPS OF TEMPLE PLACEMENTS}

Colonia Sarmizegetusa was known already from the beginning of the Middle Ages. During all this time, an ever increasing number of archaeological evidence had been removed from the site. Today, some of these monuments lie at the bottom of the Tisa river; others are scattered in different parts of Europe, with no information regarding their origin; numerous monuments are only preserved in illustrations inserted in various documents about archaeological vestiges.

134 years have passed since systematic archaeological investigations were started at Sarmizegetusa (18812015), the Roman site being known for over ten centuries. Evidently, in this interval there were some preoccupations to draw up maps of the existing monuments. Thus, L. F. Marsigli produced the first plan of the city (Fig. 1), ${ }^{9}$ and this was succeeded by the one drawn by J. Hohenhausen (Fig. 2). ${ }^{10}$

The first complex map of the archaeological monuments appeared only in 1924, being the work of Constantin Daicoviciu (Fig. 3). ${ }^{11}$ His map includes not only the investigated temples or sanctuaries, but also all of the monuments that have been discovered up to the moment when his study was published.

The second modern map was produced by Dorin Alicu in 1997 in the context of his monograph on the amphitheatre (Fig. 4). ${ }^{12}$ The shortcoming of his map is resulted from the fact that it is not accompanied by a legend. It simply states that the circled monuments were archaeologically investigated, whereas the dotted ones are just probable. The author took the points signalled by C. Daicoviciu for granted without verifying the authenticity of the edifices.

\footnotetext{
${ }^{3}$ In general for the agrimensores (or gromatici) see the monumental work of LACHMANN-BLUHME-RUDORFF-MOMMSEN 1852 which includes all the Latin texts. The studies of CHEvalLIER 1974, 649-788 and HinRICHs 1974, 224-229 are also recommended.

${ }^{4}$ For more details, see DiaconesCu 2013.

${ }^{5}$ For more details on this topic, see Joseph HILARIUS 17921798.

${ }^{6}$ Collart 1937, 224-227; also, see Pl. XXX from the Annexe for the coins linked with the colonization.

${ }^{7}$ SALOM I GARRETA 2006, 69-87.
}

\author{
${ }^{8}$ See the monument accompanied by a brief description on \\ the website of the National Museum in Aquileia (Museo Archaeolo- \\ gico Nazionale de Aquileia): http://www.arte.it/work_of_art/room-i- \\ relief-of-the-first-cut-of-the-plough-5324:Il relievo del "primo tratto \\ di aratro" (last accessed on 12.01.2015). \\ ${ }^{9}$ Marsigli 1726, 64. The part of Sarmizegetusa was later \\ taken up by SZABÓ 2004, 83-119. \\ ${ }^{10}$ Hohenhausen 1775. \\ ${ }^{11}$ DAicoviciu 1924, 224-263. \\ ${ }^{12}$ Alicu 1997, fig. 31.
}




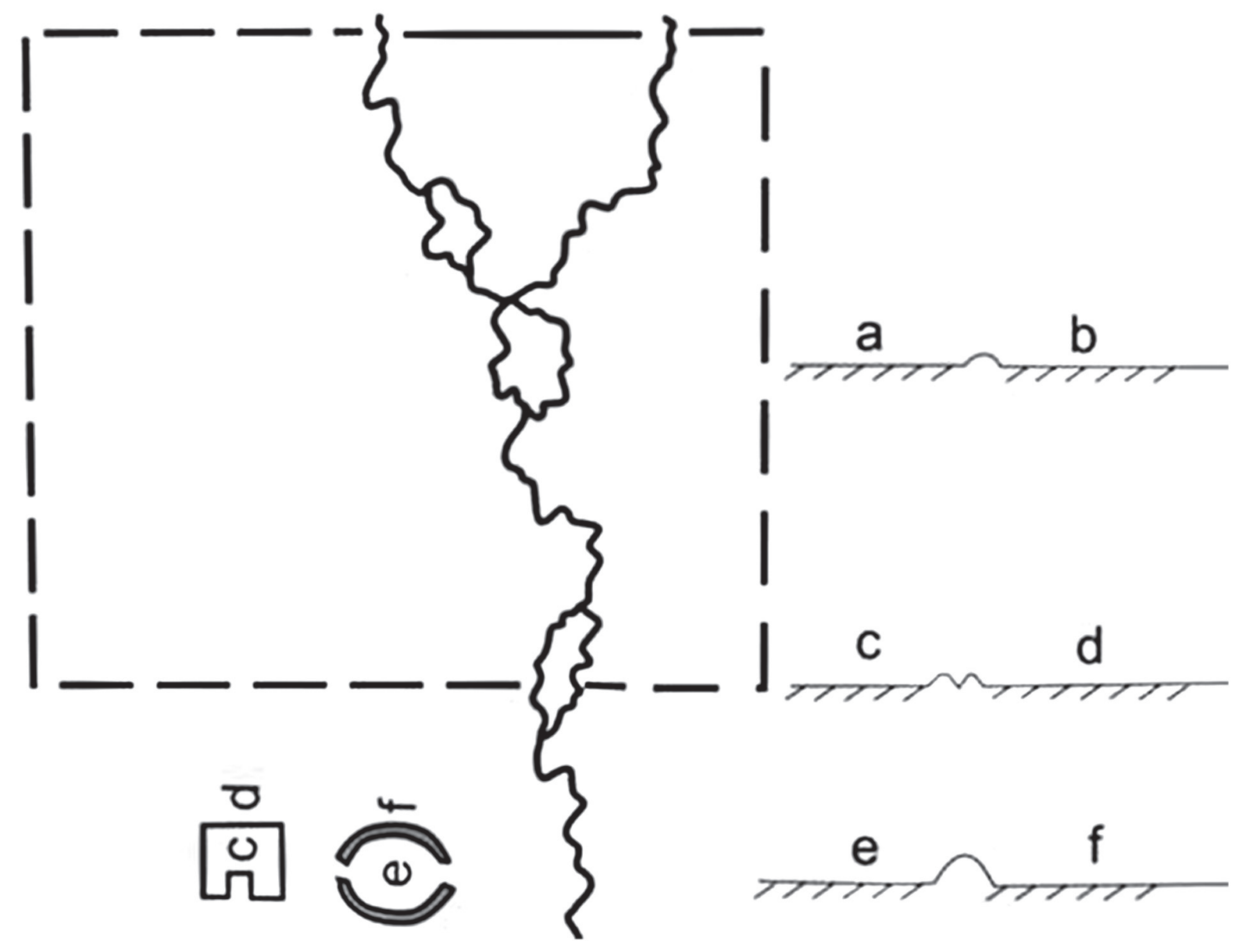

Fig. 1. Map of Colonia Sarmizegetusa after MARSIGLI 1726

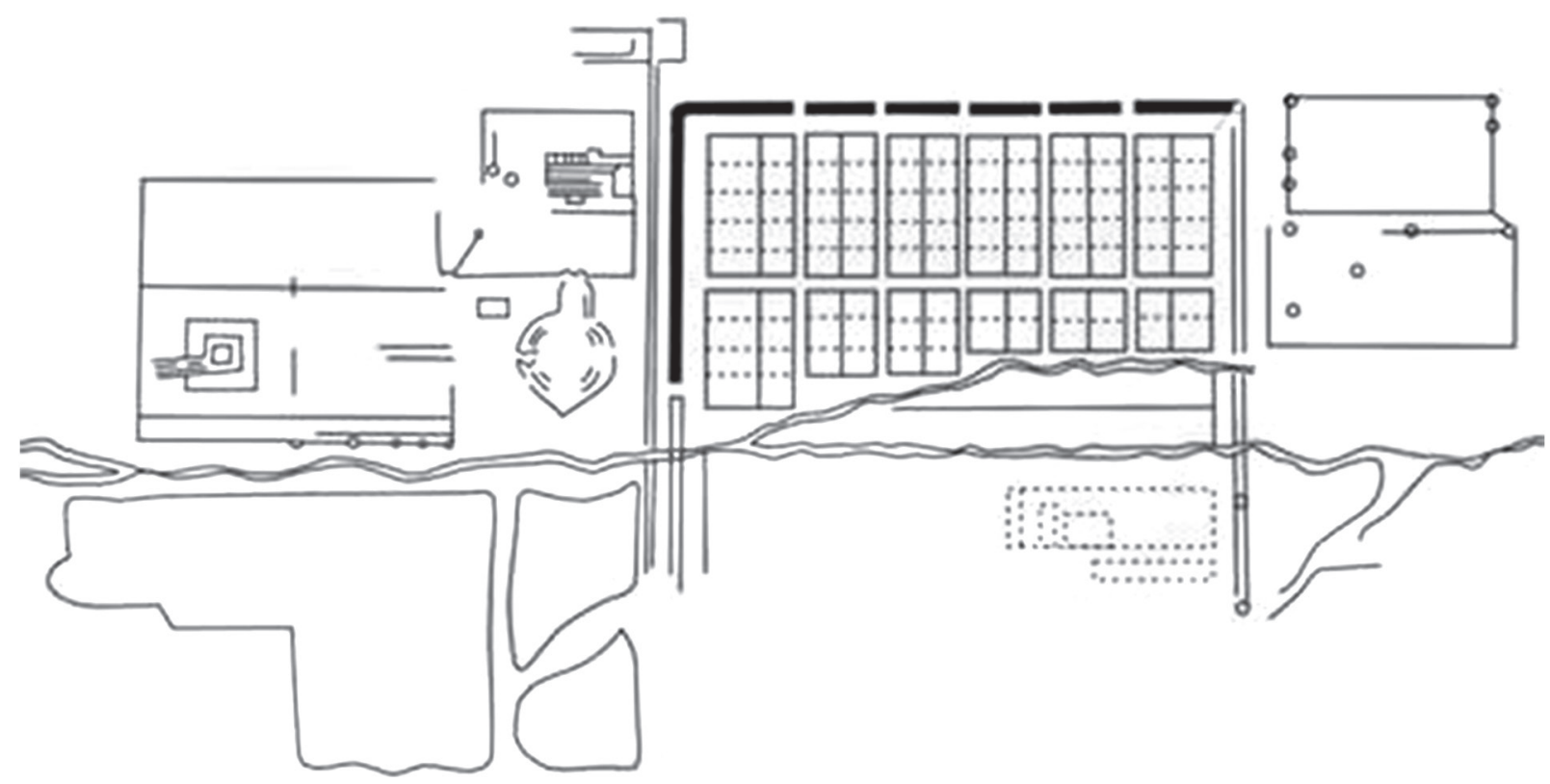

Fig. 2. Map of Colonia Sarmizegetusa after HoHENHAUSEN 1775 


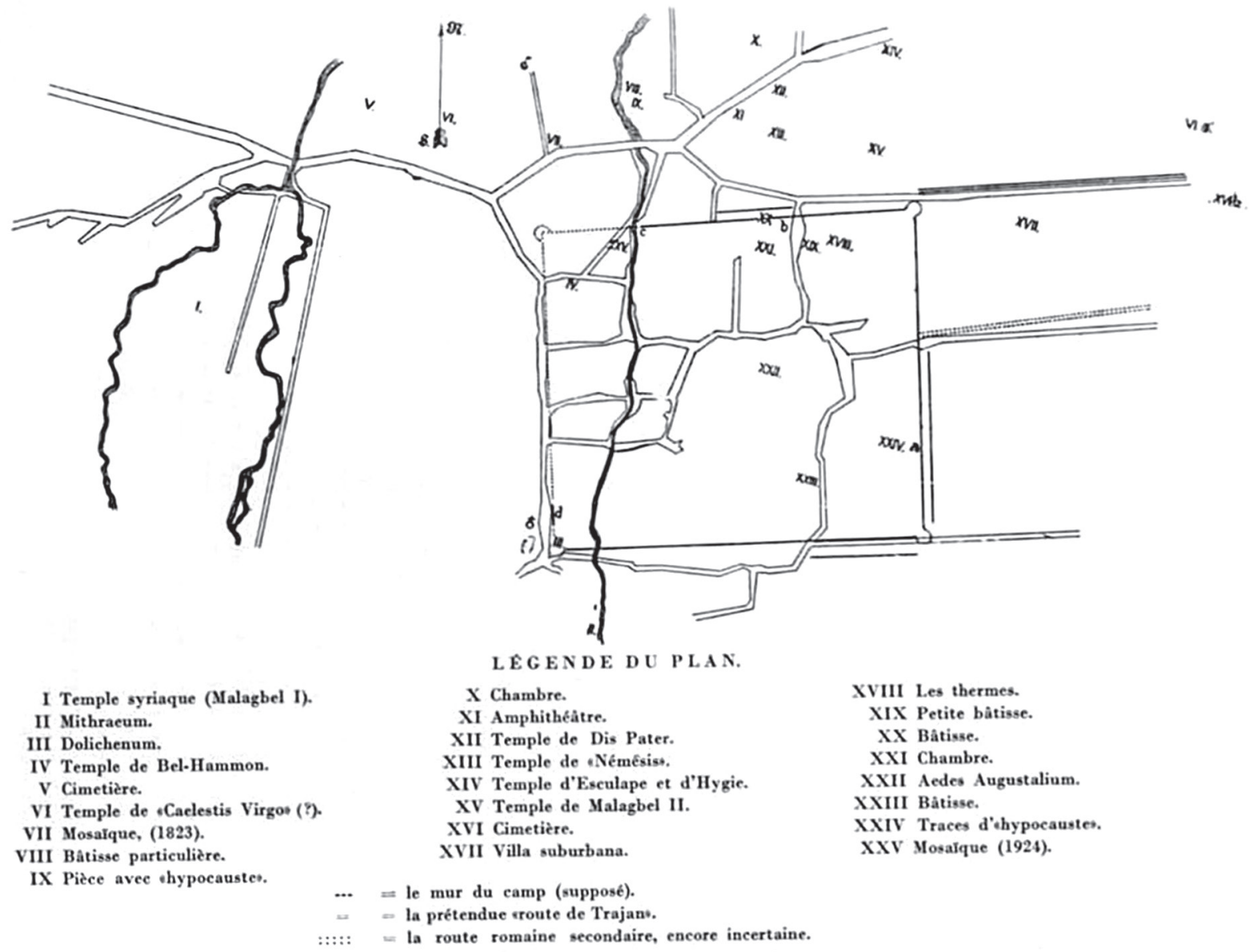

Fig. 3. Map of Colonia Sarmizegetusa after DaICoviciu 1924

Modern measurements at Sarmizegetusa were carried out between 1999-2000. On this occasion all the existing monuments were mapped, being mathematically pinpointed. ${ }^{13}$

Geophysical measurements were executed on the northern side of the town's precinct as well as around the sacred area by Manuel Fiedler and Constanza Höpken (Fig. 5). ${ }^{14}$ Even though their results were overstated, as the authors wished to prove the discovery of a series of unknown sanctuaries, they deserve credit for marking two buildings which are, indeed, newly detected (numbers 4 and 5 in their study). These lie between the temple of Dominus et Domina and the building EM 24.

The investigations carried out by Felix Marcu and George Cupcea between 2008-2010, with the new equipment and superimposing satellite measurements lead to the discovery of a series of new features of the ancient landscape and the cadastral system of Sarmizegetusa (Fig. 6). ${ }^{15}$

\footnotetext{
${ }^{13}$ ECK-LOBÜSCHER 2001, 263-269.

${ }^{14}$ FIEDLER-HÖPKEN 2010, 327-341.
} 

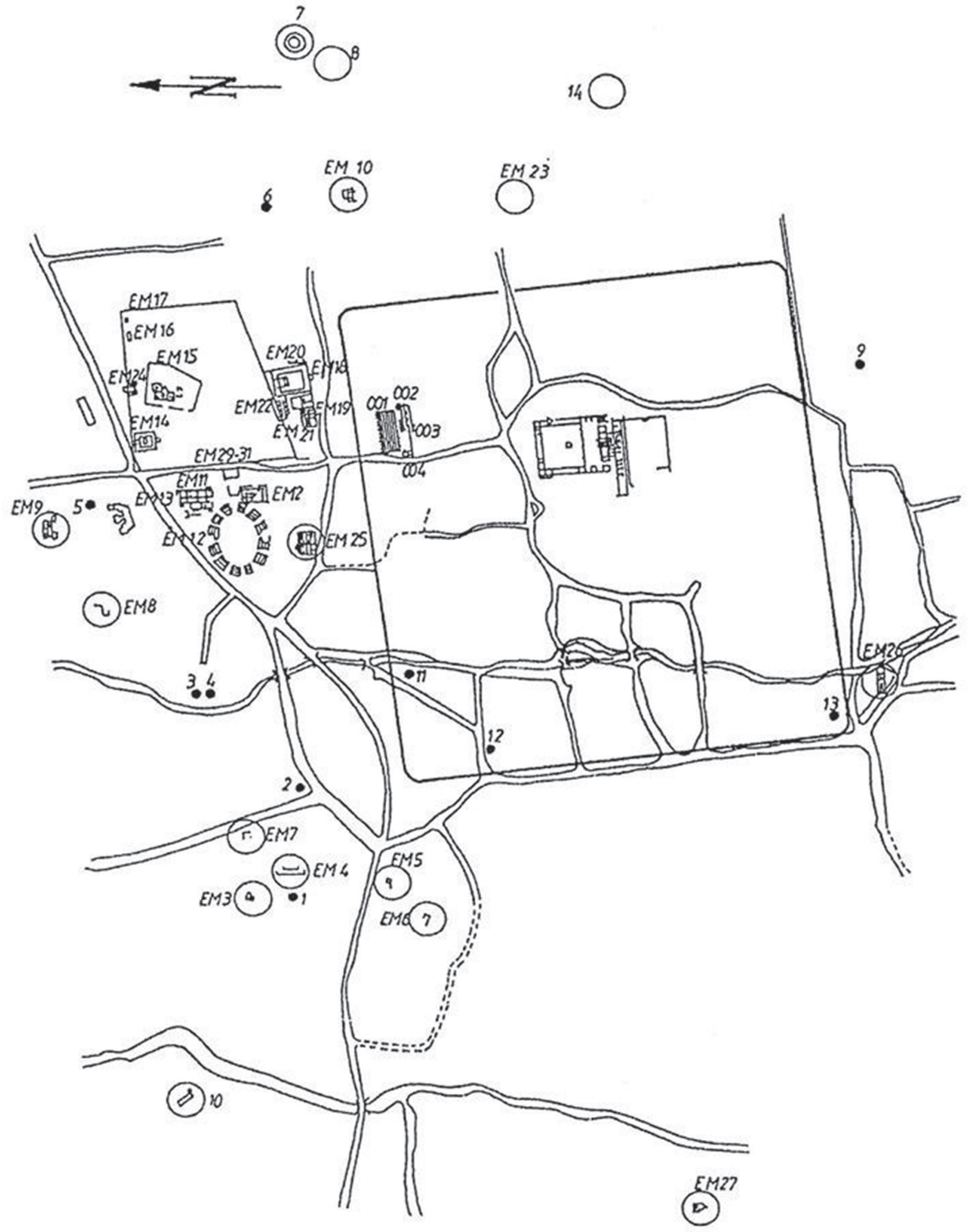

Fig. 4. Map of Colonia Sarmizegetusa after Alıcu 1997 
a

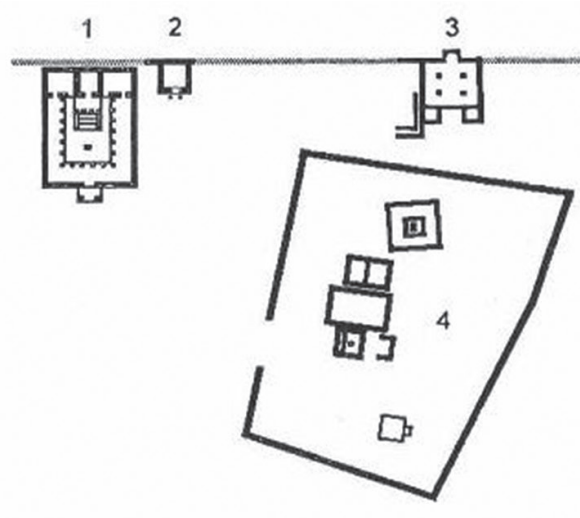

B

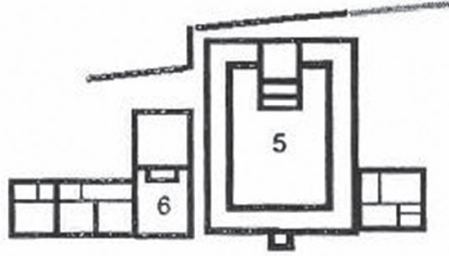

Fig. 5. Map of Colonia Sarmizegetusa after FIEDLER-HÖPKEN 2010

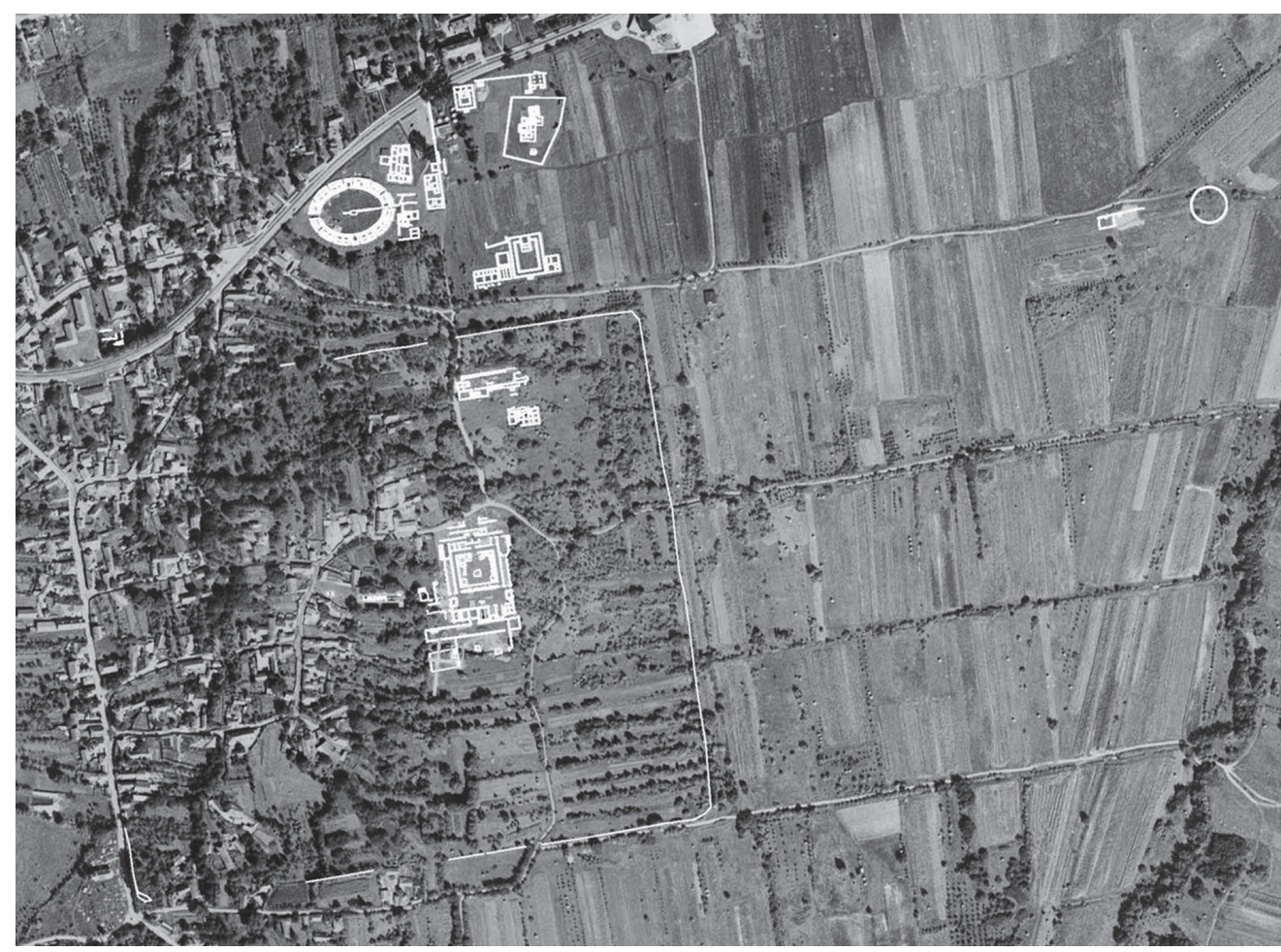

Fig. 6. Map of Colonia Sarmizegetusa after MARCU-CUPCEA 2011 
The intra muros of Colonia Sarmizegetusa

After a short introduction regarding the foundation rites of a new city, approaching the sacred topography of the colony and analysing the maps with temple/sanctuary placements drawn up to present (Fig. 7), the proper subject of this paper will be addressed in what follows.

For this I am intended to start the presentation of the archaeological monuments with the intra muros area and then moving on towards to the extra muros. Therefore at first the two forums inside the precinct (Forum Vetus and Forum Novum), as well as an area sacra inside the domus procuratoris should be singled out.

\section{Forum Vetus}

On the basis of the archaeological data it seems that the Forum Vetus was built immediately after the foundation of the colony, hence its designation as the 'Trajanic forum'. ${ }^{16}$ It played an administrative role for the colony and was designed as a compact edifice having in its centre a courtyard, the public market, surrounded on three sides by columned porticoes. These were, in turns, flanked by halls (i.e. crypto-porticoes) destined for various reunions.

The façade had a monumental entrance (propylon) provided with a four columned portico (tetrastyle) sheltering the altar for the groma, which commemorated the founding ceremony of Colonia Sarmizegetusa. ${ }^{17}$ Locus gromae was the absolute centre of the ancient city. From here the main streets of the future town started to be drawn, as well as the lots to be distributed to the colonists. ${ }^{18}$ During archaeological excavations trace of the stone block which served as the point of reference for these measurements was discovered. A marble altar was subsequently built here, in order to commemorate the foundation of the city. For not to hinder the traffic, it was placed $3 \mathrm{~m}$ to the south, but on the same cardinal axis and elevation level as the locus gromae. In course of the inauguration ceremony, a rectangular space called templum was delineated around the groma. Today, an area of $14 \mathrm{~m}$ east-west and $8.40 \mathrm{~m}$ north-south, which has in its centre the ancient spot of the groma, is clearly visible on the field. ${ }^{19}$

Right in front of the Trajanic forum, on the decumanus maximus, two nymphaea were erected. ${ }^{20}$ These were archaeologically investigated during the 1993-1994 campaigns. ${ }^{21}$ A nymphaeum is built, first of all, for practical purposes. Not everyone was allowed to have water pipes in their courtyards but only the influential and important people of the city. This is the main reason why public fountains such these were constructed.

The second motivation of this act is of religious nature. The benefactor, L. Ophonius Domitius Priscus, IIvir of the colony, dedicated these monuments in honorem domus divinae, ob merita eius in rem publica. ${ }^{22}$

Considering the expression Domus Divina, the inscription was dated to the Severan Period, which leads one to believe that the two artesian wells at the same time were monuments dedicated to the Severan family. ${ }^{23}$ It refers to divi, but more so to the living emperors by whose care the aqueduct supplying the fountains was built. Crowning the two basins of the monumental edifice there were the fountain statues that could be identified as Neptune with a Nymph for one, and Apollo and the Muses for the other. All the figures had the characteristic traits of the imperial family, an example of assimilating imperial personages into gods' representations. The expression is similar to pro salute Imperatoris, therefore the need to make the dedication to a deity. ${ }^{24}$

\footnotetext{
${ }^{16}$ For the evolution of the two fora and their furnishing with statues, see PISO-DIACONESCU 1999, 125-137. For the most recent monographic study regarding archaeological excavations of the forum, see ÉTIENNE-PISO-DiACONESCU 2006 with all of their plans. This was preceded by PISO-DiACONESCU 1985-1986, 161-183. The issue was later briefly re-discussed by Al. Diaconescu (2010 and 2013).

${ }^{17}$ Étienne-Piso-Diaconescu 2004, 101-110; ÉTIENNEPiso-Diaconescu 2006, 91-102; Diaconescu-Bota 2009, 29. For the groma altar, see: ÉtIENNE-PISO-DiACONESCU 2006, 205, B33.

${ }^{18}$ For a general bibliography on the instrument called groma, see GINOUVÈS-MARTIN 1985; ADAM 1984.

${ }^{19}$ ÉtienNe-Piso-DiACONESCU 2006, 96-98; BARBU 2014.

${ }^{20}$ For the reconstruction of the fountains, see DIACONESCU 2004, 270-273; Diaconescu-Bota 2004, 470-501; Diaconescu-
}

BotA 2009, 192-211 and Pl. 70-91. For Roman fountains in general, See LETZNER 1990; AUPERT 1974; GSCHWANTLER 1999, 545-548; MANSEL 1975, 367-372; RAKOB 1979, 375.

${ }^{21}$ For all the details regarding the archaeological report as well as the recovered material, see ÉTIENNE-PISO-DIACONESCU 2006, $120-125$.

22 Étienne-Piso-Diaconescu 2004, 120-126, pl. XLXLII, no. 110, 111.

${ }^{23}$ Domus divina is very frequently mentioned in that period, and only rarely before. See more details in ÉTIENNE-PISODiACONESCU 2006, 124.

${ }^{24}$ For this discussion, see more details in Bulzan 2005, $45-47$. 


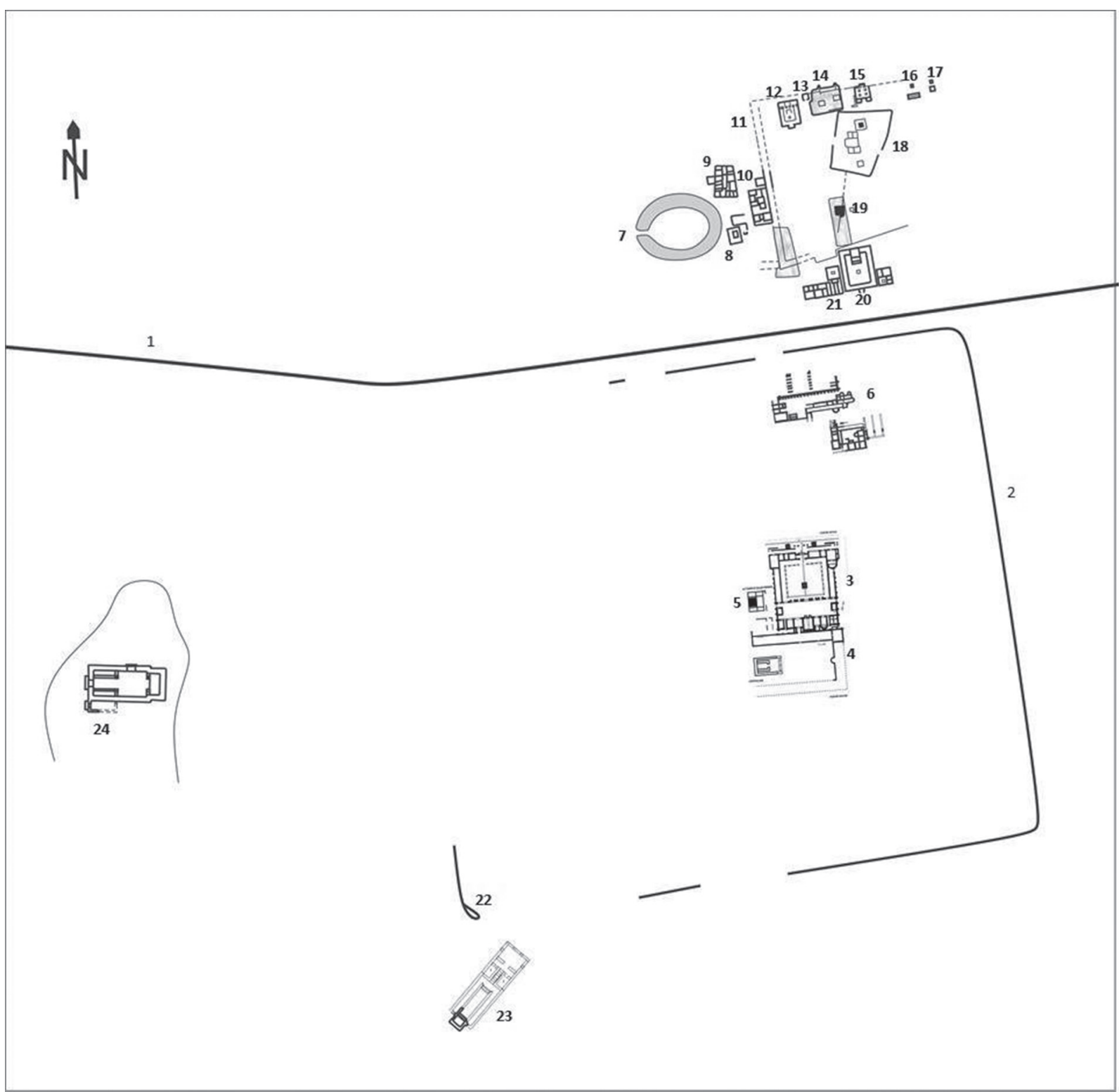

Fig. 7. Map of Colonia Sarmizegetusa after I. Boda and L. Grumeza (see in this paper). 1: Imperial Road (Drobeta-Tibiscum-SarmizegetusaApulum-Napoca-Porolissum); 2: Roman precinct of Colonia Sarmizegetusa; 3: Forum Vetus' constituent parts; 4: The capitol of the Colonia, situated on the western side of the Forum Novum; 5: Temple of Palmyrene gods; 6: Domus procuratoris: identify here a serapaeum and also an imperial temple erected for either the genius Augusti, or for the numen Augusti; 7: Amphitheatre of the colony; 8: Sanctuary of Nemesis; 9: ,Schola gladiatorum” (?); 10: Buildings EM 28-30, their purpose most probably being to connect the area sacra with the amphiteatre; 11: A $200 \times 130 \times 205 \times 122 \mathrm{~m}$ long area surrounded by a wall (temenos); 12 : Temple of Liber Pater. The god Silvanus was housed in the northwestern cubiculum of the Liber Pater temple; 13: Sanctuary of Dominus et Domina; 14: New buildings identify by the geophysical measurements (after FIEDLER-HÖPKEN 2013, 199-214); 15: Building EM 24; 16: Building EM 16; 17: Building EM 17;

18: Cultic complex around the Asklepieion; 19: Ara Augusti, identify by the geophysical measurements (after FIEDLER-HÖPKEN 2013, 199-214); 20: The „Great temple”, EM 18; 21: Sanctuary of Silvanus (?); 22: Sanctuary of Iuppiter Dolichenus; 23: Sanctuary of Mithras; 24: Sanctuary of Dii patrii palmyrene 
Next, I wish to put forward a few analogies for the two nymphaea from Sarmizegetusa, cases which were already pointed out by Alexandru Diaconescu. ${ }^{25}$ The twin fountains were built by a technique characteristic for the Greek world. In style they resemble the Severan constructions from Leptis Magna, especially the great nymphaeum. Concerning the location of the nymphaea from Sarmizegetusa with respect to the groma, the best analogy can be seen at Lambaesis, where they are to be found in a similar arrangement. ${ }^{26}$ The idea of architectural niches is frequently seen on the private nymphaea classified by W. Letzner as the type XVI (aedicule-shaped fountains), ${ }^{27}$ while the façades with three niches and water cascade stairs are encountered at the B fountain under Basilica Ss. Giovanni e Paolo in Rome. ${ }^{28}$

Reading various works about the religious life of Pannonia, I have noticed an interesting matter: according to the Hungarian researchers, when the area sacra of Gorsium was built under Trajan, pair of nymphaea were placed on its front, flanking the entrance. ${ }^{29}$ Likewise at Sarmizegetusa in front of the Trajanic forum there are similar artesian structures dated to the same time frame. The fact that during Trajan's reign a nymphaeum appears at Gorsium in front of the area sacra and one also in the forum of Sarmizegetusa is not a coincidence. Most likely this is a trend that spread at the time and is attested in the two neighbouring provinces of Dacia and Pannonia. Thus, under Trajan's rule we can observe the erection of such constructions in front of important and imposing buildings from Roman cities.

At the front of the forum, towards decumanus maximus, there was a row of chambers that served as headquarters and chapels for certain associations, such as the aedes fabrum which was archaeologically identified in its north-eastern corner. ${ }^{30}$ The foundation of a rectangular podium was located in the centre of the circle described by the apse. As demonstrated by the sacred chapel from the sanctuary of the augustales at Misenum, ${ }^{31}$ this was the place for the statue of the Genius of the association; to its left and right, on racks along the walls, there must have been the standards (vexilla) belonging to the decuriae of the fabri, attested epigraphically also at Sarmizegetusa. ${ }^{32}$ It is also known that the headquarters were provided by a banquet bed, accubitus, ${ }^{33}$ and that they also had a kitchen, culina,$^{34}$ which indicates the essential role of banquets in the activity of the collegium.

A schola, the headquarters of some collegium, was archaeologically investigated in the north-western corner of the forum. This was constructed at the same period as the aedes fabrum, and was placed symmetrically. Based on epigraphic data, the construction of the cult chapel of the fabri can be dated to the time of Commodus, which means that the schola was also built back then. Unfortunately, the building inscription of the quarters is damaged exactly at the area where it specified the type of establishment raised by the Marcii Procilii equestrian family. ${ }^{35} \mathrm{Al}$. Diaconescu thinks that they all housed imperial statues and the imperial cult took place here, based on analogies of the establishments around the forum in Pompeii and those of the so-called decumanus maximus from Herculaneum, or with the corporation headquarters of Ostia. ${ }^{36}$

From the opposite side of the entrance the courtyard was closed by a large hall named basilica sheltering only divine statues. A few official chambers were opened up towards the basilica, like the meeting room of the local council (curia), where the three statue bases dedicated by the freedmen of Ulp. Domitius Hermes originated from. The centre statue was that of Minerva Augusta, ${ }^{37}$ and on the one side there was one representing the Genius ordinis of the decurions ${ }^{38}$ while that of Concordia ordinis on the other. ${ }^{39}$ The selection of divinities made by Ulp. Domitius Hermes

${ }^{25}$ DiACONESCU 2004, 274-275.

${ }^{26}$ RАКов 1979.

${ }^{27}$ LETZNER 1990, 166.

${ }^{28}$ LETZNER 1990, TAF. 115/2.

${ }^{29}$ FITZ 1973, 7; Póczy 2004, 271-303. I wish to thank Dr. Ádám Szabó for bringing the importance of Gorsium to my attention in terms of the religious life of this town.

${ }^{30}$ Étienne-Piso-Diaconescu 2006, 105-115. Here I would like to mention the inscription IDR III/2, 13 that reveals the fact that Tib. Claudius Verus was honoured by the collegium of the fabri with a double meal at banquets (honor dubli), which means that he was allowed to have a guest. The honor biselli had the same meaning: the privilege of two seats in the front row of the amphitheatre (for this, see DiACONESCu 2004, 37). On collegia, see SCHWARTZER 2002, $221-$ 259. Regarding the collegium from Sarmizegetusa, the altar or statue base from within appears to have been raised for Fortuna Augusta on behalf of the procurator Augusti Aelius Apollinaris. The goddess was known as the tutelary divinity of this social category. See the inscription ILD 255.

${ }^{31}$ FRANCISCIS 1991. This analogy was also signalled by DiACONESCU 2004, 339-340.

${ }^{32}$ IDR III/2, 186.

${ }^{33}$ IDR III/2, 13.

${ }^{34}$ IDR III/2, 7.

${ }^{35}$ ÉTIENNE-PISO-DiaconesCu 2006, no. 34.

${ }^{36}$ DiACONESCU 2004, 148.

${ }^{37}$ IDR III/2, 271; ÉTIENNE-PISO-DiACONESCU 2006, no. 20: the dedication followed the award of decurial insignia to Ulp. Domitius Hermes (ob honorem ornamentis decurionalium).

${ }^{38}$ ÉtienNe-Piso-DiaconesCu 2006, no. 19.

${ }^{39}$ ÉTIENNE-PISO-DiACONESCu 2006, no. 18. The construction was entrusted to his freedmen as testamentary executors. 
is not random, because this was the place where trials were held and religious ceremonies of the city were carried out, activities that required the skills guarded by these divinities. Other buildings on the same side were also investigated: the archive (tabularium), the treasure chamber (aerarium), the jail (carcer), as well as an aedes Augustalium, where the augustals had a single reunion hall. ${ }^{40}$ The construction was started by M. Procilius Niceta, ${ }^{41}$ IIvir and flamen of the colony, awarded with the title of sacerdos Laurentium Lavinates, ${ }^{42}$ and was completed by M. Procilius Regulus, filius et heres. ${ }^{43}$

\section{Forum Novum}

As mentioned before, there are two forums within the city borders, evidently built at different period of time. However, the old forum was not abandoned when the newer one was set up. ${ }^{44}$ The capitol of the colonia is situated on the western side of the Forum Novum. Contrary to expectations this temple was not constructed then when the colony was founded, but only later, under Antoninus Pius' reign. ${ }^{45}$ It dominated the Forum Novum, which is therefore a religious forum par excellence. Epigraphic studies have concluded that the capitol was dedicated on the $23^{\text {rd }}$ of May (a. d. X Kal. Iunias) of an unknown year. The statue of M. Sedatius Severianus from the northern crypto-portico, dated to $\mathrm{AD} 153$, can be taken as terminus ante quem. Consequently the capitol together with the complete Forum Novum, were built sometimes between the years AD 150-153, on the $23^{\text {rd }}$ of May. Since then, each year on that day epulum Iovis (the banquet of Iuppiter), the most important celebration for Dacia, was observed in Sarmizegetusa as well as in the whole province. ${ }^{46}$

The construction of the capitol of Colonia Sarmizegetusa is not unique, not in what concerns the ground plan or the architecture, nor in the fact that it was built at later date, and not when the colony was founded.

An extended research into the religious life of Pannonia has brought to my attention the case of the capitolium from Savaria (Szombathely). Most likely it was not built under the rule of Claudius, the founder of the colony (hence the name of the city, Colonia Claudia Savaria). According to the latest interpretations, the construction of the temple dedicated to the capitoline triad occurred in the time of Domitianus, because only starting from that moment do Juno and Minerva appear sitting on the throne (earlier they were represented as standing). ${ }^{47}$

Among the best analogies for the ground plan of the capitolium of Sarmizegetusa the so-called 'Forumtempel' from Augusta Emerita Raurica ${ }^{48}$ and the capitol from Tarraco (the second phase of the edifice, when the temple becomes peripteros sine postico) can be enlisted. ${ }^{49}$ Architecturally the capitol of Sarmizegetusa has a good parallel in the temple from Augusta Emerita Raurica (Augst, Schönbühl). ${ }^{50}$

${ }^{40}$ Étienne-Piso-Diaconescu 2006, 167-169. It is noteworthy that this social category could not officiate the imperial cult at any altar or public temple, but only in its own aedes, together with that of the genius of its collegium. The headquarters of the augustals from Misenum had a scared chapel, aedes, dedicated to the Genius of the collegium, next to which there was a second chamber, the triclinium, where the banquets of the association took place. For the headquarters of collegia from Italy the works of BOLLMANN 1998; CARRILlO Diaz PINES 1995, 29-77 are fundamental.

${ }^{41}$ IDR III/2, 2: this inscription attests the fact that the sponsor erected this building for the augustals from his own funds: aedem Augustalium pecunia sua faciendum instituit.

${ }^{42}$ IDR III/2, 2, 3.

${ }^{43}$ IDR III/2, 2. Other inscriptions surfaced from this edifice thanks to archaeological excavations: an altar was set up by C. Titius Agathopus, augustal of the colonies Siscia and Sarmizegetusa (IDR III/2, 165); also a certain M. Aur(elius) Chrys(eros) dedicated an altar to Liber Pater Augustus in his role of augustal of the colony (IDR III/2, 252); another inscription mentions Fortuna Augusta but unfortunately the name of the dedicator is unknown (IDR III/2, 210).

${ }^{44}$ The fact that there is more than one forum in this particular city should not be surprising at all, since the most eloquent example can be found in Rome itself (see underneath). A further and very good example could be Colonia Patricia Corduba (Córdoba, Es), the headquarters of the province Baetica. The first forum (Forum Coloniae) was discovered inside the enclosure and it was erected shortly after the foundation of the colonia. Not long after, a new forum was built (Forum Novum) and in its enclosure a temple was also erected, which dominated the total space of the forum and was solely dedicated to the Imperial Cult. Aside from all of the before mentioned forums, the forum of the provinciae should be enumarated as well (Forum Provinciae), which was situated right outside of the enclosure. For more information see MuRILLO 2010, 71-93, fig. 4.

45 TÉglás 1890, 149-154; Piso-Marcu-ŢenteA-CuPCEA-VARGA 2012, 119-124. Inscriptions for Iuppiter: IDR III/2, 234-239, 245, 247, 248; ILD 249; Epulo Iovis: IDR III/2, 242; Inscriptions for Iuno: III/2, 190, 230, 232-233, 240, 245, 248, 249.

${ }^{46}$ Piso-Marcu-TुEnTEA-Cupcea-VARga 2012, 119-124.

${ }^{47}$ Paulovics 1940, 19-47. E. Tóth has got to this conclusion by analysing the fragmentary statues discovered, which allowed him to state that they were not parts of the same group of figures (То́тн 1971, 143-169=1973, 19-31).

48 TRUNK 1991, 34-44, 154-160.

49 Ruiz De Arbulo-Vivó-Mar 2006, 391-418; MarRuiz de Arbulo-Vivó 2010, 39-70; Mar-Ruiz de Arbulo-Vivó 2011, 507-540; MAR-RuIZ DE ARbulo-Vivó 2014, 37-68.

50 TRUNK 1991, 34-44, 160-171. 
Remaining inside the Roman precinct, the discovery of a new temple dedicated to the Palmyrene triad (Bel?, Malagbel, Iarhibol), located right next to the Forum Vetus on its western side, has to be mentioned. It was raised in the time of Severus Alexander. It could not have been built earlier, because only with this emperor starting does the cult of the Palmyrene gods benefit from official support in the Roman Empire and even at Sarmizegetusa, where the cult of Malagbel was very popular. It should also be pointed out that the worshippers frequenting this temple (conventionally called Malagbel III) were exclusively Romans and were associated into a religious collegiums. ${ }^{51}$ This implies the existence of an association of individuals that watched over the cult of these divinities, having the temples of the collegiums in their custody, attended the sacrifices and took care of the expenditures.

\section{The area sacra from domus procuratoris}

The headquarters of the financial procurator of Dacia Apulensis (domus procuratoris) was built on the path from the Forum Vetus heading to the northern gate of the Roman precinct. This construction enclosed an area sacra.$^{52}$ As expected, all the monuments originating from this spot were exclusively put up by procuratores Augusti, some of whom dedicated them together with their wives.

The evidence recently collected and thoroughly analysed by Ioan Piso enabled him to identify here a Serapaeum and also an imperial temple erected for either the genius Augusti, or for the numen Augusti. ${ }^{53}$

In fact, the presence of cult buildings inside praetoria throughout the Empire is not unusual. The best illustration of this situation is to be found in Dacia. The epigraphic documentation indicated the existence of a Serapaeum at Apulum, inside the headquarters of the governor of the three Dacias. ${ }^{54}$

The above mentioned scholar, I. Piso, puts forth other examples of Serapaea built within praetoria in the same period. ${ }^{55}$ Thus he recalls the one from Eburacum (York) in Britannia, constructed during the reign of Septimius Severus, around the year AD 190. ${ }^{56}$

Other parallels for this type of religious manifestations can be seen at Carnuntum, where a certain P. Cornelius Anullinus rebuilt the temple of Serapis, ${ }^{57}$ or at Ad Statuas (Pannonia Inferior), where a temple was raised for the health of Caracalla and of Julia Domna. ${ }^{58}$

Returning to the Serapaeum from Sarmizegetusa, the presence of a few fountains is an interesting phenomenon. Their occurrence around Isiac temples is attested in the case of the two largest Isaea, that is the ones from Savaria ${ }^{59}$ and Pompeii. ${ }^{60}$ The existence of wells and pipes that supplied the water indicate their use not only for the lustration rites of these so-called 'oriental' cults (purgatorium, lavracum), but also for the most important celebration, the navigium Isidi.

According to I. Piso's interpretation, the imperial cult was supposedly observed in another archaeologically investigated edifice from the area sacra. This is documented by a single inscription dated to the time of Severus Alexander. ${ }^{61}$

The appearance of such sanctuaries in the praetoria all over the Empire is not an out of the ordinary sight. As analogy, the headquarters of the governor from Aquincum can be mentioned. The edifice built here seems to have been dedicated to the imperial cult. The inference is grounded in a statue of Nemesis-Fortuna (through whose effigy the loyalty towards Julia Domna was expressed) and in another statue that represents a man in a toga. ${ }^{62} \mathrm{Un}-$ fortunately, this construction can no longer be identified in the field, as it was destroyed by the Danube.

The religious behaviour of the governors manifested in the perimeter of the area sacra of the palace is extremely interesting: following their taking office (thus, in their official quality), one after another they raise an

${ }^{51}$ PISO-ŢENTEA 2011, 1-11.

52 Piso-ŢENTEA 2011, 1-11.

${ }^{53}$ PISO 1983, 233-251; PISO 1998, 253-271; PISO 2013 , $181-258$.

${ }^{54}$ Diaconescu-Piso 1993, 72-73; IDR III/5, 319; DEAC-

VARGA 2014, 11-19.

${ }^{55}$ PISO 1998, 257, note 20.

${ }^{56}$ CIL VII $240=$ RICIS 604/0101; PISO 1998, 257, note 20;

D. Deac considers that the legate mentioned in this inscription did not build the temple for Serapis in the context suggested by I. Piso, but later, when the Egyptian cults become the protectors of the Severan dynasty (DEAC 2014, 45).

${ }^{57}$ RICIS 613/0703.

${ }^{58}$ AÉ 1947, 36; AÉ 2000, 1202; RICIS 614/0501.

${ }^{59}$ About the Fontaine in around of Iseum see the work of P. BALÁzs $(2012$, 69-75). The excavation was erected by O. Sosztarits, between 2001 and 2010 .

${ }^{60}$ H. То́тн 2005, 233-252.

${ }^{61}$ Piso 1998, 261-262, no. 6. 
altar for Iuppiter, a fact that is documented both epigraphically and archaeologically. Apart from these, a large-sized statue of a headless man clad in a toga was found. The archaeologists noticed that his head was missing not because of some destruction, but because he was made that way right from the start. Their interpretation, which I hold to be correct and furthermore practical for the Romans, is explained by the fact that the head of the emperor in office was attached to the body. This is the way in which the official cult was performed in the palace of the governor from Aquincum, by affixing the head of ruling emperor following his accession to power. ${ }^{63}$

An interesting aspect is the fact that on these epigraphic documents there are no closing formulas, which, according to I. Piso, suggest the possibility that they were dedicated merely as 'work duty'. ${ }^{64}$

\section{The northern side of the Roman precinct}

Coming from the forum one made one's way to the amphitheatre on the cardo maximus, a road which, after exiting the city gate, was parallel to the small axis of the entertainment arena. The relations of axiality, alignment or proximity are all part of the scenic display of the monuments specific to Roman imperial architecture, with the purpose of bringing together the edifices that were part of the same complex. The placement, orientation, as well as the scenography and progression transcribe into materiality human gestures and processions of a sacred nature; they are the expression of a symbolic religious geography. ${ }^{65}$

Walking just a few metres to the north, on the western side of the road that exits through the northern gate, one can observe the amphitheatre of the colony. Southwards from it there is the temple of Nemesis, ${ }^{66}$ archaeologically identified on the spot, and towards the north lies the temple of Diana, ${ }^{67}$ which, unfortunately, was not detected by archaeological excavations; we know of its existence thanks to inscriptions and topographical descriptions referring to their find spot.

Opposing these constructions there is an area of $200 \times 130 \times 205 \times 122 \mathrm{~m}$ long territory surrounded by a wall (temenos). Various sacred constructions were built inside it. The fact that a sacred area should appear surrounded by a wall is not something unusual, quite the contrary. To prove this, it suffices to remember just a few towns with a similar state of affairs: Augusta Raurica, ${ }^{68}$ Aquincum (the area sacra with its 14 springs, north-west from the fort), ${ }^{69}$ Brigetio (outside the porta decumana of the fort, near the aqueduct), ${ }^{70}$ Carnuntum-Pfaffenberg (after exiting the eastern gate of the fort), ${ }^{71}$ Savaria, where there was an area sacra for the so-called 'oriental' cults (sacra peregrina); however, this last instance is a little different, as this area is sectioned by the Via Sucinaria (Hung. Borostyánkö út). ${ }^{72}$

${ }^{62}$ PÓCZY 2004, 184.

${ }^{63}$ PóCZY 2004, 271-303. The statues are kept in the Aquincumi Múzeum (1031 Budapest, Szentendrei út 135). They were analysed and photographed by the author $(23.03 .2015)$. I would like to thank the staff at the museum for allowing me access to the required material.

${ }^{64}$ I wish to thank I. Piso for this insight.

${ }^{65}$ At Sarmizegetusa, I. Piso and Al. Diaconescu (PISODAICONESCU 1985-1986, 161-183) made use of the axiality relationship between the location of the amphitheatre and the area sacra north of the edifice. The researches place next to the supposed location of the imperial altar (Ara Augusti) the temple of Roma and Augustus (Templum Romae et Augusti), the centre of the provincial imperial cult (see their plan from page 162, fig. 1: Sarmizegetusa, general plan, spot no. 8). It is also legible in their study that this complex can be regarded as a third forum of Sarmizegetusa.

${ }^{66}$ SzINTE 1897, 35-37; DAICOVICIU-Alicu 1984, 107-109; Rusu-Pescaru-Alicu 2000, 61-65; SCHÄFER 2007, 53-55. Inscriptions for Nemesis: IDR III/2, 308, 310-327; AÉ 2006, 1174. The placement of the sanctuary with respect to the amphitheatre has an analogy at Flavia Solva (Noricum); for more detailed information, see HudECZEK 1977, 444-451; HudECZEK 1989, 39-40; SCHMIdT 1919 , 149-150; DieZ 1959, 13-14; Bouley 1989-1993, 105-125.

${ }^{67}$ Rusu-PESCARU-Alicu 2000, 144-146. The inscription IDR III/2, 198 set up by Ianuarius comes from the northern part of the Roman precinct, and the one listed in IDR II/2, 198, put by Felix, from the Great Temple.

${ }^{68}$ ZSIDI-FURGER 1997.

${ }^{69}$ Zsidi-Furger 1997; PócZy 2004, 275; PÓCZY 1980, 3-29.

70 Póczy, 2004, 99; Póczy 1980, 3-29. At Brigetio it is necessary to resume archaeological excavations in order to be absolutely sure that there was a temenos. However, considering the present archaeology and the discoveries from the area, there are good chances of such a situation, according to the opinion of László Borhy. I wish to express my gratitude to Acad. Prof. Dr. László Borhy for the academic discussions regarding the archaeology of Brigetio.

${ }^{71}$ PÓCZY 2004, 99; HUMER 2010.

${ }^{72}$ Balla 1967, 67-76; Mráv 1998, 217-236; Paulovics 1943; SoszTARITs 1994, 233-241. I wish to thank Dr. Ottó Sosztarits for the academic discussions regarding the archaeology of Savaria. 
Coming back to Sarmizegetusa, the Romanian researchers noticed a row of temples built on the same axis (i.e. the northern side of the temenos). From west to east, these are the temple of Liber Pater, ${ }^{73}$ the sanctuary of Dominus et Domina ${ }^{74}$ and the cult edifice EM 24 (the so-called 'Basilica'). ${ }^{75}$ The geophysical investigations conducted by M. Fiedler and C. Höpken ${ }^{76}$ discovered two additional buildings (numbers 4 and 5 on their map), located between the Dominus et Domina sanctuary and EM 24. According to the illustrated plan, these two are not exactly aligned on the axis, but a bit offset to the south. They are smaller buildings and unfortunately in the lack of archaeological investigations nothing is known about their function.

Going further towards the interior, there was the cult compound pertaining to the Asklepieion ${ }^{77}$ which was also surrounded by a temenos, and also the buildings EM 16 and EM 17. The latter were labelled as sacred constructions, although the only argument in favour of this interpretation is that they are enclosed by the temenos, alongside other temples and Graeco-Roman sanctuaries. ${ }^{78}$ For all we know, they could have had a different purpose, related nonetheless with the surrounding temples. Unfortunately, they can no longer be seen on the spot, because a hotel was built on that location and the archaeological reports from the rescue excavation are only brief. ${ }^{79}$

Several buildings lining the southern side of the temenos were archaeologically investigated, but their exact role still remains uncertain. The so-called temple of Silvanus can be cited here. It was assigned to this particular god because a relief representing him accompanied by the nine Silvane was found there. ${ }^{80}$ We know that the god was housed in the north-western cubiculum of the Liber Pater temple, where there was a shrine for him. Adriana Rusu-Pescaru and D. Alicu claim that after the Marcomannic wars Silvanus was 'moved' from his original place and on this occasion a new edifice was attributed to him. ${ }^{81}$

On the eastern side of the presumed edifice for Silvanus lays the largest temple from Dacia know to date. It was archaeologically investigated and, due to its size, the researchers conventionally called it the 'Great Temple' ${ }^{82}$ However, in the archaeological literature it is also found under different designations, such as 'EM 18', 'the temple of multiple divinities', 'Malachbel', 'the temple of Hercules and Diana'. ${ }^{83}$

The epigraphic data attests here the presence of Juno (and with her, implicitly, the capitoline triad), Hercules and Diana. By the courtesy of I. Piso, who indicated a new inscription to me, I am able to mention yet another divinity from this temple, one whose name ends in 'TRI', i.e. Libero Patri. Thus, the sanctuary sheltered Iuppiter, Juno, Minerva, Hercules, Diana and Liber Pater, who become the tutelary deities of Dacia. All this was placed under the imperial aegis, since the supreme gods of Rome (the triad) are present, and the other divinities bear the epithet Augustus. ${ }^{84}$

Concerning my personal reflections about the intension of this temple, I wish to fix the following ideas: a) in the first place, knowing that it is the largest archaeologically investigated temple from the province, this suggests right from the start that it was meant for some very important gods; b) these gods would have been firmly established both in Sarmizegetusa in particular, and in Dacia in general; c) it was built in a sacred place, which is the southern side of the temenos, near the Ara Augusti.

I will next proceed with a few analogies to demonstrate that these divinities can be found together in the same edifice; thus, they are considered tutelary divinities of a town, or of a province, as in the above mentioned instance.

${ }^{73}$ IDR III/2, 11; DAICOVICIU-ALICU 1984, 109-116; RUSUPESCARU-Alicu 2000, 52-58; SCHÄFER 2007, 55-61. Inscriptions for Liber Pater: IDR III/2, 250-261.

${ }^{74}$ FIEDLER-HÖPKEN 2013, 199-214.

75 Daicoviciu-Alicu-Piso-Pop 1989-1993, 407-433; ALICU-PoP-Cociș1993, 441-442.

${ }^{76}$ FIEDLER-HÖPKEN 2010, 327-341.

77 Daicoviciu-Alicu 1984, 116-123; Rusu-PescaruALICU 2000, 32-42; SCHÄFER 2007, 64-72. Inscriptions found in the cult complex: IDR III/2, 151-165, 167-176, 178-182. Inscriptions originating from around the fountain: IDR III/2, 166, 183 (mentions the fountain of Aesculapius). Next to the Mithraeum: IDR III/2, 177. Inscriptions for Iuppiter: IDR III/2, 239.

${ }^{78}$ Rusu-Pescaru-Alicu 2000, 109-112.
${ }^{79}$ Buildings EM 20, 22, 29, 30, 31: Rusu-Pescaru-Alicu 2000, 109-112.

${ }^{80}$ PISO-Rusu 1977, 155-158.

${ }^{81}$ Daicoviciu-Alicu 1984, 127-129. Inscriptions for Silvanus: IDR III/2, 332-337.

82 Daicoviciu-Alicu 1984, 123-127; Rusu-PescaruAlicu 2000,114-119.

${ }^{83}$ DAicoviciu-Alicu-PIso-PoP 1979, 139-154; DaicoVICIU-Alicu 1981, 83-84; DaicoviciU-Alicu 1984, 123-127; RusuPescaru-Alicu 2000, 114-119; Schäfer 2007, Kat H.II; Ciongradi-Diaconescu-Bota-VoIşAn-BĂEŞTEAn 2014, no. 78, 113-114. For the archaeological material, see ALICU 1994, 10.

${ }^{84}$ I wish to thank prof. Dr. Ioan Piso for presenting me with this inscription as well as for all the information regarding the destination of the temple. 
One of the most important aspects refers to the fact that from a scientific point of view we are discussing about the so-called tutelary deities „Tutelae” and the major role they played in specific cities. These tutelary deities where widespread in the whole Roman Empire, a fact which can be easily denoted from various inscriptions. ${ }^{85}$ We would like to use the situation of Tarraco as an example, where, besides the fact that inscriptions indicate the presence of a "Tutelae Tarraconensis" ${ }^{86}$ there is also an archaeologically investigated temple dedicated to this specific deity. ${ }^{87}$ Every city had its own protective deity, as we can see for example in case of Sarmizegetusa with a Genio Coloniae Sarmizegetusae ${ }^{88}$ and in Tarraco the Genio Coloniae Iuliae Urbis Triumphalis Tarraconensis. ${ }^{89}$ These particular cases are refered to as 'el culto de lugar', as it was well defined and interpreted by G. Alföldy in the year $1988 . .^{90}$

Since Sarmizegetusa represents the headquarters of the three provinces of Dacia, we therefore also have religious manifestations of provincial importance. It is important here to mention two altars erected and dedicated by procuratores Augusti, because they indicate the presence of Genio Daciarum ${ }^{91}$ and most likely Fortuna Daciarum (?). ${ }^{92}$

All Roman cities, based on their preferences and their necessities was able to incorporate their own gods, next to these Tutelae or Genio. They were able to defend the main gods of the city or the province, either being mentioned in the same place, or having taking shelter in a temple by itself.

The first to bring forward is the temple of the August Genius of Colonia Marciana Traiana Thamugadi, which was situated on the decumanus maximus, immediately westwards from the Trajanic enclosure. ${ }^{93}$ The edifice comprised a courtyard surrounded on three sides by porticoes and having in its centre a large altar. The proper chapel was built on an elevated platform reached by a monumental staircase. The three statue bases seen on the long side belong to the capitoline triad, while the two bases on the short side were meant for Liber Pater and Silvanus. Since these statues were all present in the original design plan of the edifice, it is obvious that the protective divinities of the town were practically honoured in the cult place of the colony's Genius. All this is under imperial backing, since the supreme gods of Rome, the triad, are there, and the rest of the divinities were given the epithet Augustus. The edifice was built around AD 167-169 and this is the place where a series of statue bases subsequently dedicated to personifications of special meaning for the imperial propaganda originates from. ${ }^{94}$

As further analogies, representative for 'combining' divinities in such a way, an inscription from Györ (Hungary) ${ }^{95}$ is worth bringing into attention. It mentions that, during the reign of Severus Alexander, a military man together with his wife rebuild a dilapidated temple for the capitoline triad, Liber Pater and Diana. Thus, the only god who is missing is Hercules, but he is very popular in Dacia. ${ }^{96}$

The aforementioned cases prove that these deities can share a temple, being the tutelary divinities of a colony, as seen at Thamugadi, and even of a province.

The issue of the Ara Augusti

In the year 1985, I. Piso and Al. Diaconescu have got to the conclusion that the Ara Augusti (in which the cult of the living emperor was celebrated at provincial level) was situated east from the amphitheatre, between the 'Great Temple' and the Asklepieion ${ }^{97}$ This construction was not archaeologically investigated; however its traces

${ }^{85}$ For this information see Epigraphik-Datenbank ClaussSlaby (EDCS), http://db.edcs.eu/epigr/epi_ergebnis_en.php.

${ }^{86}$ RIT 37, 51, 52, 53, 54, 55, 56.

${ }^{87}$ The temple can be found at the crossing of the streets Pons de Ixart and Menden Nunez, Tarragona. With this particular occasion I would like to address my sincere thanks and gratitude to Prof. Dr. Joaquín Ruiz de Arbulo (Universitat Rovira I Virgili, Tarragona, ES), for the scientific discussions on the topic of the city Tarraco and also for being kind enough to present the archaeological investigations that were taking place while I was doing my research in that specific area. ${ }^{88}$ ILD 281

${ }^{89}$ RIT 23.

${ }^{90}$ ALFÖLDY 1988, 7-26.
${ }^{91}$ IDR III/2, 217.

${ }^{92}$ IDR III/2, 209.

${ }^{93}$ EINGARTNER 1992, 213-242.

${ }^{94}$ See the analogy also presented by Al. DiACONESCu 2004, $322-325$.

${ }^{95}$ CIL III, 11079: I(ovi) O(ptimo) M(aximo) / Iunoni Regin(ae) / Minervae Nep/tuno Libe(ro) pat[ri] / Dianae ceteris[que] / dibus L(ucius) Anton(ius) Sa/binianus cornic(ularius) / leg(ati) leg(ionis) I Ad(iutricis) P(iae) F(idelis) Se[v(erianae)] / templum vetu[st(ate)] / conlapsum fa/ciumdum cur(avit) / cum Aur(elia) [A] eliana / con(iuge).

${ }^{96}$ [Dr. A. A.] $1920-1922,12-14$.

${ }^{97}$ Piso-Diaconescu 1985-1986, 182, no. 133. 
can be very clearly observed on the plan provided by M. Fiedler and C. Höpken. ${ }^{98}$ The location is supported by various finds. In 1969, an altar dedicated to Mars Augustus, for the genius or more likely for the numen of an emperor, by M. Antonius Valentinus, sacerdos Arae Augusti was discovered here. ${ }^{99}$ This is also the place where the fragment from a votorum carmen surfaced in $1964 .{ }^{100}$ In addition to these epigraphic data, another argument in favour of the hypothesis is the relation of axiality between the altar and the amphitheatre. The placement of an edifice meant for observing the cult of the living emperor at the level of the province at Sarmizegetusa, between the colony's sanctuaries (some of which date back to the time of Trajan), is not anomalous, because the northern side of the Roman precinct was exclusively occupied by Graeco-Roman temples.

Based on Marsigli's map and description, Ádám Szabó situates here both the Ara Augusti, and the provincial forum; ${ }^{101}$ previously, I. Piso and Al. Diaconescu also opted for this variant. ${ }^{102}$

For the presence of a construction that served for celebrating the imperial cult of the living emperor for the whole province the following analogies can be listed: in Hispania Tarraconensis (Tarraco), ${ }^{103}$ Gallia Narbonensis (Narbo), ${ }^{104}$ the three Gauls (Lugdunum), ${ }^{105}$ Raetia (Cambodunum), ${ }^{106}$ Noricum (Virunum), ${ }^{107}$ Britannia (Camulodunum) ${ }^{108}$ and Pannonia (Savaria). ${ }^{109}$

Despite the fact that the practice of the imperial cult differed by making use of a temple or of an altar, being run accordingly by a flamen provinciae, a sacerdos provinciae, or a sacerdos Arae Augusti, the common denominator was the position of these sacred constructions in an extra muros area; the only exception is Camulodunum, where the temple of the founder emperor was built in the forum of the town. ${ }^{110}$

The provincial altar at Lugdunum should also be added to these examples. It measured $40 \mathrm{x} 40 \mathrm{~m}$, which represents $1 / 3$ of the total area of the courtyard. This was the centre of the three Gauls, and the provincial priest bore the title of sacerdos ad Aram. To date this is the best analogy for the situation at Sarmizegetusa, which was at the centre of the three Dacias. ${ }^{111}$

The sanctuaries erected for the celebration of the living emperors' cult all have in common the fact that they are surrounded by temples, by various cult constructions. At Lugdunum, next to these buildings there is the amphitheatre, while at Tarraco and Savaria we find the theatre. The creation of a sacred area demanded the existence of a nearby structure in which to continue and to finish the spectacles started in the temples of the city. This situation can be encountered not only at Sarmizegetusa, but also in the case of the other towns indicated as analogies for imperial temples/sanctuaries. An interesting arrangement is seen at Augst/Schönbühl, where one can notice a direct link between an area sacra and the amphitheatre situated vis-à-vis from it, just as at Sarmizegetusa. ${ }^{112}$ This is the best analogy for the staging of these structures.

The problem of the provincial forum

A few monuments found west from the amphitheatre attracted the attention of Al. Diaconescu. ${ }^{113}$ If they were not indeed brought from elsewhere and merely reused here, they would become very important pointers for the placement of the provincial forum. The statue base dedicated Dis Faventibus et Concordiae Imp(eratoris) by the

${ }^{98}$ FIEDLER-HÖPKEN 2010, 327-341.

${ }^{99}$ IDR III $/ 2,266$

${ }^{100} \mathrm{IDR}$ III/2, 241. For the votorum carmen, see DAICOVICIU 1967, 6 (non vidi). MĂRGHITAN-PETOLESCU 1974, 245-247; MĂRGHITANPetolescu 1976, 84-86; Piso 2005, 39-50; NeMETi 2015, 251-262.

${ }^{101}$ SZABÓ 2004, 83-119.

102 Piso-DiACONESCU 1985-1986, 161-183.

103 TED'A 1989, 141-191; ALFÖLDY 1978, 572-644; HÄNLEIN-SCHÄFER 1985.

104 GAYRAUd 1969, 304-316; HÄNLEIN-SCHÄFER 1985, 239.

105 AUdin 1956; SüsSEnBACH 1989, 73-96. The delegation met annually on the $1^{\text {st }}$ of August. For this information, see CRAMER 1927, 1720; HÄNLEIN-SCHÄFER 1985, 246.

${ }^{106}$ LORENZ 1987, 129, 141, 144; HÄNLEIN-SCHÄFER 1985, 277.
${ }^{107}$ HARL 1989, 521-598

${ }^{108}$ LORENZ 1987, 129, 135-136, 162.

109 Tóth 2001, 5-33; BREDETZKY 1804.

${ }^{110}$ According to Á. SZABÓ (2004, 83-119) who disagrees with D. Fishwick $(1977,31-50)$ in the case of Camulodunum the temple might actually be municipal, and not provincial. At Savaria there was also a temple raised for the founding emperor, Claudius, but it was located outside the city precinct, in the forum (MRÁv 1998, 217-236).

111 This theory was advocated before in the Romanian literature, the first to propose it being R. ARDEVAN (1998, 328-342).

112 NeUOKOM-RADTKE 1997,114

${ }^{113}$ DiACONESCU 1998, 342 
council, ${ }^{114}$ the bronze head of Decius, the leg of an imperial statue, a wing from a bronze Victory statue, all constitute significant clues for locating a provincial edifice. Alongside cult monuments, there must have been a large sized forum situated by the amphitheatre. Perhaps this is the only acceptable indication regarding the westwards placing of this provincial forum. ${ }^{115}$

Speaking of the location of this forum we can see that two theories took shape. According to the first, it was situated on the northern side of the Roman precinct, where the area sacra was located. This idea was first expressed by I. Piso and Al. Diaconescu ${ }^{116}$ and was later restated by Á. Szabó, following the analysis of Marsigli's map. ${ }^{117}$ The second theory was voiced by Al. Diaconescu, who places the provincial forum westwards from the amphitheatre.

Considering the two theories and analysing both the epigraphic and the archaeological evidence, I personally opt for the first variant. The main reasons for this are the presence of the Ara Augusti and the temples for Liber Pater-Libera and Aesculapius-Hygia, deities who appear under imperial aegis, bearing the epithets Augustus,- $a{ }^{118}$ not the least, the importance and significance of the 'Great Temple' supports this option. In addition, there is the analysis carried out by Á. Szabó based on Marsigli’s map, who places the provincial forum in this area. Besides, there are no certainties that the aforementioned monuments from the western side of the amphitheatre really do come from here: the possibility that they were brought from elsewhere cannot be ruled out.

\section{The north-western side of the Roman precinct}

Inscriptions point to the existence of three temples on this side of the Roman enclosure. Unfortunately, these could not be archaeologically verified, nor confirmed by geophysical investigations, because villages started to extend in this area since as far back as the Middle Ages.

Epigraphy and topographical descriptions indicate a temple for Isis, ${ }^{119}$ the earliest built amongst the cult edifices on this side, during the reign of Marcus Aurelius. ${ }^{120}$ Apart from it the epigraphic evidence prove the existence of a temple raised for the African goddess Caelestis Virgo, who has the epithet Augusta, ${ }^{121}$ and of another for Sanctus Malagbel (the so-called Malagbel I edifice), ${ }^{122}$ both being built under the Severan period.

The north-western area of the Colonia where new edifices were built mainly starting with the Severan period coincides with a space in which temples for the divinities supported by emperors were emplaced. Only this context would explain their presence near the Graeco-Roman temples.

These constructions prove the fact that the same religious events that took place in Rome also happened in Sarmizegetusa, but at a later date: the so-called 'oriental' temples start being built on the Aventine in Rome; similarly beginning with the Severan emperors they appear at Sarmizegetusa near the sacred area which was enclosed by the temenos.

\footnotetext{
${ }^{114}$ Honorific basis for P. Furius Saturninus, governor of Dacia Superior between 159-161/162, raised by the provincial council immediately after his departure from the office, as a sign of gratitude for exempting the entire province of certain obligations, oneribus relevaverit, enforced by the previous governor, M. Statius Priscus. He had imposed these legal burdens probably connected with supplying the troops with grain and means of transportation during the crisis of 158. For the whole discussion, see Piso 1993, 75.

${ }^{115}$ For such colonial forums, see an example from Pannonia: Tóтн 2001, 5-33. The Hungarian scholar, in his catalogue, presents each piece originating from the forum of Savaria, which was situated to the west of the colony, between a hill and the Perint stream.

${ }^{116}$ Piso-Diaconescu 1985-1986, 161-183.

${ }^{117}$ SzABó 2004, 83-119.

${ }_{118}$ At Apulum, the epithet Augustus, $-a$ is not used for the medicine gods, except for maybe just one case. Therefore, it adds to
}

the reasons for defining the area as an 'official' one. For a more detailed discussion, see BULZAN 2005, 46.

119 IDR III/2, 19; Rusu-Pescaru-Alicu 2000, 140. Inscriptions for Isis: IDR III/2, 228.

${ }^{120}$ See a more detailed discussion at D. Deac (DEAC 2014 $46,55)$, with all the older bibliography.

${ }^{121}$ TÉGLÁs 1914, 350-354; IDR III/2, 17; DAICOVICIU 1924, 232 (the scholar claims that the inscription was found in the garden of Litsek, but traces of a large building, probably the temple of the goddess, were still visible). Rusu-PESCARU-ALICU 2000, 140-141. The temple of the African goddess was built in the time of Septimius Severus.

122 Daicoviciu 1924, 229 (the researcher calls it Malagbe II); Rusu-Pescaru-Alicu 2000, 77; IDR III/2, 262. The temple was built under Septimius Severus' rule. 
The north-eastern side of the Roman precinct

An altar dedicated to Malagbel by T. Flavius Aper, scriba of Sarmizegetusa, was found in the north-eastern corner of the enclosure. ${ }^{123}$ This is also the find spot of a limestone relief (discovered in 1889 by the HTRT Association $)^{124}$ depicting personages in martial attire who, according to I. Piso, probably represent the Palmyrene triad. These are also briefly mentioned in the study of C. Daicoviciu, although he wrongly states that the inscriptions were found in the north-western corner of the 'fort' in 1889, without further details; he labels this temple as Malagbel III. ${ }^{125}$

The south, south-western and western side of the Roman precinct

Here, archaeological investigations (as 'systematic' as they could be at that time) were started already in the $19^{\text {th }}$ century. ${ }^{126}$ Back then, the directors of the excavations, G. Téglás and P. Király, successively unearthed the temple of the Palmyrene gods Dii patrii (in the year 1881), ${ }^{127}$ and the Mithras sanctuary (between 1882-1883), ${ }^{128}$ and they also mentioned a temple dedicated to the Syrian god Iuppiter Dolichenus (1886). ${ }^{129}$

Due to subsequent destructions today these temples can no longer be identified in the field, and they could not be located by geophysical measurements either. Nevertheless, thanks to the Hungarian texts that carefully describe the situation, I was able to pinpoint them on the plan of Sarmizegetusa. These monuments date from the time of Severus Alexander, who, because of his origin, expressed a preference for these deities, the cult of Malagbel becoming an official one during his reign.

To conclude, this area seems to be reserved for the worshippers of 'oriental' cults. Topographically speaking, all these buildings are rather wide apart (the distance between the Mithraeum and the Dolichenum appears to be an exception). Seemingly, they did not constitute an area sacra, but were built wherever there was some free space; in any case, opposite to the Graeco-Roman sanctuaries.

From the point of view of the religious life, the case of Savaria is very important, especially with respect to the temple of Isis and its surroundings. Analysing the topography of this city, ${ }^{130}$ we can observe that new temples were gradually built for 'oriental' divinities (sacra peregrina) around the temple of Isis. Thus, sanctuaries are attested for Iuppiter Dolichenus, Iuppiter Depulsor, Magna Mater, Mithras(?). Interestingly, the Isaeum remained the focus of this area sacra. Consequently, the circumstance described above leads to the conclusion that this space was meant for the 'oriental' cults, the temples within constituting a sacred area. The nearby inhabitants were probably of oriental descent, this last observation being supported by Lajos Balla's analysis of the onomastics of the population from Savaria. ${ }^{131}$

${ }^{123}$ IDR III/2, 264

${ }^{124}$ Hunyadvármegyei Történelmi és Régészeti Társulat (History and Archaeology Association of Hunedoara County).

125 DAicoviciu 1924, 230

${ }^{126}$ BODA 2014, 307-351.

127 IDR III/2, 18; TÉGLÁs 1906, 321-330; DAICOVICIU 1924, 228 (the researcher designates this temple as Malagbel I); RusuPescaru-Alicu 2000, 84-90; Diaconescu 2011, 148-158.

${ }^{128}$ KUUN 1886, 85; KIRÁLY 1886; KIRÁly 1894, 134-151; Daicoviciu 1924, 228 (the Romanian scholar wrote that this was the first feature observed by the Association between the years 18811883. Hungarian texts clearly state that the archaeological investigations were carried out between 1882-1883, after the unearthing of the so-called Syrian temple); Daicoviciu-Alicu 1984, 68-70; RusuPesCARU-Alicu 2000, 81-84; SCHÄFER 2007, 93-98. Inscriptions for Cautopates: IDR III/2, 193. Inscriptions for Mithras: IDR III/2, 273306. The inscription for the god Nabarzes: IDR III/2, 307. Regarding the possibility of the existence of two Mithraea, see Kun-TormaTÉGLÁs 1902, 75; ALICU 2002, 221-222; BoDA 2014, 307-351.
129 IDR III/2, 29; KuUn-Torma-TÉGLÁs 1902, 87; DAICOVICIU 1924, 230 (the researcher presumes that it was found in the south-western corner of the 'fort' between the years 1884-1885); Rusu-Pescaru-Alicu 2000, 154-155; SZabó 2007, 77, 95-96, $98-100,115,117,215$. Inscriptions that mention Dolichenus: IDR III/2, 202-204. S. NEMETI $(2005,224-235$, 352-366; 2012, 82-83) observes a connection between Iuppiter Dolichenus and Deus Aeternus (in Dacia), stating that numerous ex voto-s were found in the large centres such as Sarmizegetusa, Apulum and Ampelum where the cult of Dolichenus was extremely popular. At Sarmizegetusa, three inscriptions dedicated to Deus Aeternus were discovered together with an altar for Dolichenus and a bas-relief depicting an eagle that grips an animal in its claw (the theme of this image is specific to the Dolichenian cult; for this discussion, see BoDASZABÓ 2011, 273-282, fig 7). 1994, 233-241.

${ }^{130}$ I. TóтH 1998, 329-336; Tóth 1971, 151; SosztaRits

$$
{ }^{131} \text { BALLA 1963, 225-237. }
$$


A similar situation is encountered at Carnuntum, where we also have temples dedicated to so-called 'oriental' gods, such as Iuppiter Heliopolitanus, Iuppiter Dolichenus, Mithras and Cybele, constructions which also make up a sacred area. ${ }^{132}$

I mentioned these examples because I wanted to show that sometimes the spread of the 'oriental' cults is of major significance, and also that multiple edifices can constitute a sacred area. Although this is not the case at Sarmizegetusa, here a temple for Malagbel was built right next to the Forum Vetus. All these cults became prominent at some point in time, but this is reflected in particular ways in different cities within of the Empire.

\section{Concluding remarks and the issue of temples for Dea Roma and Divus Traianus}

After the ceremony occasioned by the foundation of the colony and after outlining the main roads (cardo maximus and decumanus maximus) starting from the locus gromae, the first forum of the town was built, the socalled 'Trajanic forum', or Forum Vetus. The foundation was carried out by the governor of Dacia, Decimus Terentius Scaurianus, who was in office starting from AD $109 .{ }^{133}$ Initially, the forum was built in wood, ${ }^{134}$ but, shortly afterwards, still during Trajan's reign, a larger stone forum was built from rocks and limestone blocks by a detachment (vexillatio) of legio IIII Flavia Felix.

At the same time, or in the shortly following years, the sacred edifices from the northern side of the Roman enclosure were built, that is, those located in the area sacra delineated by a temenos. What substantiates this claim? As summarized above, this side was reserved for the traditional Graeco-Roman edifices and for the Ara Augusti, so it is only natural that this area should be populated by constructions first, and not that where the so-called 'oriental' temples are located. Furthermore, this theory is also supported by inscriptions and stratigraphy: we know that under Marcus Aurelius these temples were already in existence because they were damaged in the Marcomannic wars. ${ }^{135}$ Of course, as expected, they were renovated through the years, but their initial destination remained the same until the end of Roman Dacia.

As observed, the Roman-oriental cults gradually became widespread thanks to the troops arriving from the Orient. The space allotted to these divinities for raising temples in the Colonia Sarmizegetusa was situated on the southern, south-western and western side of the precinct.

But why were the edifices in question built in that area? The northern side was already occupied by the traditional temples and there was simply no room (further to the north lay Roman houses), whereas the temples officially sanctioned by Rome were situated on the north-western and north-eastern sides, without being grouped in a sacred area. Also we cannot leave out the necessity of a separation between these edifices from a topographic point of view: in the time of Trajan or Hadrian, the building of 'oriental' temples amid the traditional ones, near the Ara Augusti, was not acceptable. These sorts of temples were erected only starting with the Severans.

In the course of time, Roman emperors placed themselves under the protection of various divinities, for whatever reason. Augustus, for instance, put himself under the protection of Apollo (following the help he received in the battle of Actium), or under the aegis of Venus, the patron of the Julia gens. Commodus especially favoured the spread of Egyptian cults. Septimius Severus saw himself as Bacchus, Hercules, Iuppiter and Serapis. Julia Domna assumed the guise of Juno, Cybele, and above all Caelestis, while Caracalla pretended to be the new Hercules and Dionysus. ${ }^{136}$ Steadily, these gods would slip into the official religion of Rome, exactly because of the emperors who supported the dissemination of their cults within the Empire. Thus, their temples start to appear inside or near the Roman precinct. Based on epigraphy and topographic descriptions, the temple of Isis can be recalled, ${ }^{137}$ which is the earliest from the north-western side, built under Marcus Aurelius. ${ }^{138}$ In addition, due to inscriptions, the raising of

\footnotetext{
${ }^{132}$ HUMER 2010; Póczy 2004, 99.

${ }^{133}$ PISO 1993, 13-18.

${ }^{134}$ For the Trajanic wooden structures, see ÉTIENNE-PISODiACONESCU 1994, 147-164 = ÉTIENNE-PISO-DiACONESCU 2006, 41-65.

${ }^{135}$ Daicoviciu-Piso 1975, 159-163.

${ }^{136}$ For this discussion, see the following fundamental works dedicated to the imperial cult: ÉTIENNE 1956, Fishwick's vol-
}

umes I (FISHWICK 1987), II (FISHWICK 1991), III (FISHWICK 2002, Fishwick 2004, Fishwick 2005). For Dacia, see the thesis of S. BULZAN (2005).

${ }^{137}$ IDR III/2, 19; RUSU-PESCARU-ALICU 2000, 140. Inscriptions for Isis: IDR III/2 228.

${ }^{138}$ See the discussion in Dan DEAC $(2014,46,55)$ with all the previous references. 
a temple for Sanctus Malagbel (so-called Malagbel I) ${ }^{139}$ can be confirmed for the time of Severus Alexander, who officially supported the Palmyrene cult. During Septimius Severus' reign (193-211) a temple was built for Caelestis Virgo on the north-western side of the precinct.

After Severus Alexander, between the rules of Maximinus (235-238) and Aurelianus (270-275) no new edifices appear to have been constructed. Only reconstruction work on the existing temples could be observed in this time frame. Obviously, religious manifestations did not come to a halt, because there are altars and statues dedicated to various divinities dated to this period. Religious life certainly continued, but the expansion of the sacred topography of the city, the building of temples, had reached its peak at the latest by AD 235, when Sarmizegetusa is granted the title Metropolis.

The issue of a temple for Dea Roma

According to the analogies presented from certain cities within the Empire, there are at least two buildings missing from Sarmizegetusa. Angelo Brelich, in his vast study on the religious life of Aquincum, points out the fact that the foundation of a town is in fact an 'imitation of Rome'. Thus, it follows logically that Rome did not set the basis of the cult of Dea Roma, but the provinces. ${ }^{140}$ This fact is clearly evidenced in the case of Augusta Raurica ('Hauptforum'), where there is a shared temple for the goddess Roma and for Augustus, the founder of the colony.

It can be rationally assumed that such a temple also existed in Colonia Sarmizegetusa, but this raises the question of its location within the town. So far, there are four possibilities, four areas in which sacred constructions were observed: 1) in the Forum Novum, next to the capitol (we know that this was a religious forum);2) in the area sacra of the domus procuratoris, next to the building erected for the genius or for the numen of the August emperor, as seen for example in Aquincum; ${ }^{141} 3$ ) in the area sacra from the northern side of the enclosure, near the Ara Augusti, similar to the cases presented above; 4) in the provincial forum, hypothetically located by Al. Diaconescu westwards from the amphitheatre.

After analysing the sacred topography of the Colonia Sarmizegetusa in comparison to the placement of cult edifices from various towns of the Empire, I can state that there definitely was a temple for the goddess Roma. I believe that it was situated either in the Forum Novum, a religious forum par excellence, just as in the case of Augusta Raurica, ${ }^{142}$ or in the area sacra, near the Ara Augusti, as suggested by I. Piso and Al. Diaconescu. The two scholars consider that the temple might have been built for Roma et Augustus. ${ }^{143}$

In one of his articles, based on numerous analogies, Zsolt Mráv proves the fact that there was no temple for Roma et Augustus at Savaria, for the simple reason that the city did not exist in the time of Augustus. The cited parallels indicate that such temples were only built either during Augustus' reign, or during Tiberius', as for instance at Ostia and Leptis Magna. ${ }^{144}$ On these grounds I find it hard to believe the theory proposed by I. Piso and Al. Diaconescu regarding the existence of a common temple for Roma et Augustus; instead, there certainly was a temple dedicated to the goddess Roma.

The issue of a temple for Divus Traianus

After consulting the relevant literature, I do not think that the possibility of a temple for Divus Traianus, the founder of the colony, is far-fetched at all. This situation is encountered at Augst 'Hauptforum' where an edifice for Roma et Augustus exists, ${ }^{145}$ at Pola for the same pair, ${ }^{146}$ or at Savaria,with its temple dedicated solely to Divus Claudius, the founder of the city. ${ }^{147}$ A temple for Divus Traianus is known in Hispania as well, at Italica. ${ }^{148}$

\footnotetext{
${ }^{139}$ DAICOVICIU 1924, 229 (the researcher designates the edifice as Malagbel II); RUSU-PESCARU-ALICU 2000, 77; IDR III/2, 262.

${ }^{140}$ BRELICH 1938, 20-142. With respect to the religious life from Aquincum see also the study of G. ALFöLDY (1963, 47-69).

${ }^{141}$ A statue was found here representing goddess Roma sitting on a throne, only her head was missing. For an in-depth discussion, see KÁDÁR 1963, 71-83.

${ }^{142}$ ZSIDI-FURGER 1997.
}

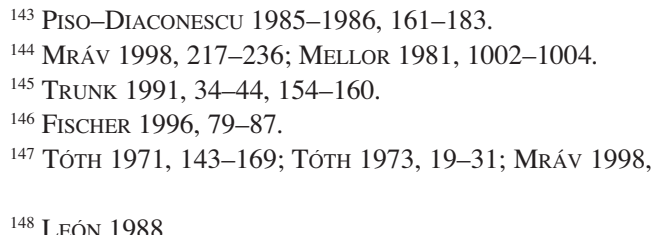
217-236.

$$
{ }^{148} \text { LEÓN } 1988 .
$$


A question to be addressed is the location of these temples. They were usually built in the city forums, or even near them. In the Forum Romanum from Rome we find the temples of Divus Iulius, ${ }^{149}$ Divus Vespasianus, ${ }^{150}$ Divus Antoninus-Diva Faustina, ${ }^{151}$ while that of Divus Traianus lay in the Forum Traiani.

On the basis of these examples, I can only state that both temples were built either in the Forum Novum, or in the area sacra that stretched on the northern side of the Roman enclosure. If we accept the theory according to which the temple or temples were rather built in the area sacra of the colony, this would add to the list of arguments for identifying the provincial forum. Unfortunately, I cannot opt for one of these variants in the lack of inscriptions which could determine their placement. The only certainties are the existence of a temple for the goddess Roma and one for Divus Traianus, and their probable location in either of the two aforementioned areas, as suggested by the examples noted above.

To conclude, I should like to point to the existence of a cult compound surrounding the Asklepieion, which in turns was included in the area sacra from the northern side of the city precinct, enclosed by a temenos. Inside it Graeco-Roman temples were constructed around the Ara Augusti. The second area sacra was found in the domus procuratoris. The divinities worshipped here were of various origins, but raising a temple for an Isiac divinity (in this case) was only possible starting with the reign of Caracalla. Regarding the so-called 'oriental' temples, these do not appear to be concentrated in a particular spot, in a sacred area of their own, but are rather dispersed. However, I can affirm that they could only be built on the southern, south-western and western side. From the moment when an emperor placed himself under the aegis of a particular god, the importance of the latter automatically increased, entailing the construction of temples inside the Roman precinct, as clearly illustrated, among others, by the case of the Colonia Sarmizegetusa.

\section{ACKNOWLEDMENTS}

This work was possible due to the financial support of the Sectorial Operational Program for Human Resources Development 2007-2013, co-financed by the European Social Fund, under the project number POSDRU/159/1.5/S/132400 with the title „Young successful researchers - professional development in an international and interdisciplinary environment".

\section{REFERENCES}

[DR. A. A.] $1920-1922$

ADAM 1984

ALFÖLDY 1963

ALFÖLDY 1978

ALICU 1994

ALICU 1997

Alicu 2002

ALICU-PoP-CocIș 1993

ANDRINGA 2012

ARDEVAN 1998

AUPERT 1974
= [A. ALFöLDI]: Kapitóliumok Pannoniában [Capitolia in Pannonia]. ArchÉrt 39 (1920-1922) 12-14.

= J.-P. ADAM: La construction romaine materiaux et techniques. Paris 1984.

$=$ G. ALFÖLDY: Aquincum vallási életének története (Geschichte des religiösen Lebens in Aquincum). BudRég 20 (1963) 47-69.

= G. ALFÖLDY: Tarraco. PWRE Suppl XV. Stuttgart 1978, 572-644.

= D. Alicu: Opaiţele romane / Die römischen Lampen. Bucureşti 1994.

= D. Alicu: Ulpia Traiana Sarmizegetusa. 1: Amphiteatrul [Amphiteatre]. Cluj-Napoca 1997.

= D. Alicu: Addenda la repertoriul templelor din Dacia [Addenda to the repertory of the temples in Dacia]. Apulum 39 (2002) 201-235.

= D. ALICU-C. Pop-S. Cocıș: Săpături arheologice la Ulpia Traiana Sarmizegetusa (1985-1989) [Archaeological excavations in Ulpia Traiana Sarmizegetusa (1985-1989)]. ActaMN 26-30 (1993) 435-458.

= W. VAN ANDRINGa: Statues in the temples of Pompeii. Combinations of gods, local definition of cults, and the memory of the city. In: Historical and Religious Memory in the Ancient World. Ed. by B. Dignas, R. R. R Smith. Oxford 2012, 83-118.

= R. ARDEVAN: Viaţa municipală în Dacia romană [Municipal Life in Roman Dacia]. Timişoara 1998.

= P. AUPERT: Le nymphée de Tipasa et les nymphées et „Septizonia” nord-africaines. Collection de l’École Française de Rome 6. Roma 1974.
${ }^{149}$ NASH $1961-1962,512-513$.
${ }^{150}$ NASH $1961-1962,501-504$.

Acta Archaeologica Academiae Scientiarum Hungaricae 66, 2015
${ }^{151}$ NASH 1961-1962, 26-27. 
AZARA-MAR-SUBIAS 2001

BALLA 1967

Balázs 2012

BARBU 2014

BODA 2014

BoDA-SZABÓ 2011

BOLLMANN 1998

BOULEY 1989-1993

BULZAN 2005

BREDETZKY 1804

BRELICH 1938

CARANDini-CAPELli 2000

Chevallier 1974

CiONGRADI-DiACONESCU-BOTA-

VOIȘAN-BĂEȘTEAN 2014

Collart 1937

CORNEL 1999

DAICOVICIU 1924

DAICOVICIU 1967

DAICOVICIU-Alicu 1981

DAICOVICIU-Alicu 1984

DAICOVICIU-PISO 1975

DAICOVICIU-Alicu-PISO-PoP 1979

DEAC 2014

DEAC-VARGA 2014

DiACONESCU 2004

DIACONESCU 2010

DiACONESCU 2013

DiACONESCU- Bota 2004

DiACONESCU-Bota 2009
= P. Azara Nicolás-R. Mar Medina-E. Subías Pasqual: Mites de fundació de ciutats al món antic (Mesopotàmia, Grècia i Roma). Actes del Colloqui Internacional. Barcelona 2001.

= L. Balla: Zur Geschichte des religiösen Lebens von Savaria. ACUSD 3 (1967) 67-76.

= P. BALÁzs: A savariai Iseum kútja [The fountain of Iseum in Savaria]. Ókor 11/3 (2012) 69-75.

= M. BARBU: Materiale şi tehnici de construcţie utilizate la realizarea clădirilor din fazele de piatră ale coloniei Ulpia Traiana Augusta Dacica Sarmizegetusa [Materials and Construction Techniques Used in Order to Build Structures on Stone Phases of Colonia Ulpia Traiana Augusta Dacica Sarmizegetusa]. Ph.D. Thesis. Cluj-Napoca 2014.

$=$ I. BoDA: Ulpia Traiana Sarmizegetusa and the archaeological research carried out between 1881 and 1893. Studia Antiqua et Archaeologica 20 (2014) 307-351.

= I. BodA-Cs. SzaBó: Notes on a Dolichenian relief at Mehadia. Marisia 31 (2011) 273-282.

= B. BollmanN: Römische Vereinshäuser. Untersuchungen zu den Scholae der römischen Berufs-, Kult- und Augustalen-Kollegien in Italien. Mainz 1998.

= E. Bouley: Le culte de Némésis et les jeux de l'amphithéâtre dans les provinces balkaniques et danubiennes. ActaMN 26-30 (1989-1993) I/1, 105-125.

= S. Bulzan: Cultul imperial în Dacia romană.[The Imperial Cult in Roman Dacia] Ph.D. Thesis. Cluj-Napoca. Cluj-Napoca 2005.

= S. BREDETZKY: Beyträge zur topographie des Königgreichs Ungarn. III. Wien 1804.

= A. BRELICH: Aquincum vallásos élete (La religiosità di Aquincum). Laureae Aquincenses memoriae Valentini Kuzsinszki dicatae. I. DissPann 2:10. Budapest 1938, 20-142.

= A. CARAndini-R. CAPElli (ed.): Roma, Romolo, Remo e la fondazione della città. Roma 2000.

$=\mathrm{R}$. Chevallier: Cité et territoire. Solutions romaines aux problèms d l'organisation d l'espace. Problèmes et solutions. ANRW II:1. Berlin-New York 1974, 649-788.

= C. Ciongradi-Al. Diaconescu-E. Bota-V. Voişan-G. BăEȘtean: Ulpia Traiana Sarmizegetusa, Templul Mare şi Poarta de nord nr. 78. CCA 2014, 113-114.

= P. Collart: Philippes. Ville de Macedoine. Depuis ses origines jusqu'a la fin de l'époque romaine. Paris 1937.

= T. J. CoRnel: Los orígenes de Roma. Barcelona 1999.

= C. Daicoviciu: Fouilles et recherches à Sarmizegetusa. Dacia 1 (1924) 224-263.

= C. DAicoviciu: Tainele Ulpiei Traiana. Ritmuri hunedorene (suppl. Drumul Socialismului), 8 (Dec.), Deva 1967, 6 (non vidi).

$=$ H. Daicoviciu-D. Alicu: Edificii de cult la Upia Traiana Sarmizegetusa. 1. ActaMN 18 (1981) 83-84.

= H. Daicoviciu-D. Alicu: Colonia Ulpia Traiana Augusta Dacica Sarmizegetusa. Bucureşti 1984.

= H. DAICoviciu-I. PISO: Sarmizegetusa şi războaiele marcomanice (Sarmisegetusa et les guerres marcomannes). ActaMN 12 (1975) 159-163.

= H. Daicoviciu-D. Alicu-I. Piso-C. Pop: Principalele rezultate ale săpăturilor din 1975-1977 la Ulpia Traiana Sarmizegetusa şi semnificaţia lor (Die Hauptergebnisse der Ausgrabungen von 19751977 von Ulpia Traiana Sarmisegetusa und ihre Bedeutung). Sargetia 14 (1979) 139-154.

= D. DEAC: Prezența şi influențele egiptene la Dunărea de Mijloc şi Jos [The Egyptian Influences and Presence in the Middle and Lower Danube: the Pannonian, Dacian and Moesian Provinces (I-IV c. AD)]. Ph.D. Thesis. Cluj-Napoca 2014.

$=$ D. DEAC-R. VARGA: Isiac cults in the Settlements of Apulum (Dacia Apulensis). Bibliotheca Isiaca 3 (2014) 11-19.

= AL. DiACONESCU: Statuaria majoră în Dacia romană [Major Statuary in Roman Dacia]. Cluj-Napoca 2004.

$=$ AL. DiACONESCU: Forurile Sarmizegetusei. O plimbare imaginară prin centrul politico-administrativ al micii Rome de la Poalele Retezatului [The forums of Sarmizegetusa. An imaginary walk in the political-administrative centre of the „little Rome” at the base of the Retezat Mountain]. ClujNapoca 2010.

$=$ Al. DiACONESCU: Forurile Sarmizegetusei. O plimbare imaginară prin centrul politico-administrativ al micii Rome de la Poalele Retezatului [The forums of Sarmizegetusa. An imaginary walk in the political-administrative centre of the „little Rome” at the base of the Retezat Mountain]. ClujNapoca $2013^{2}$

= Al. Diaconescu-E. Bota: Epigraphy and archaeology. The case of the two recently excavated nymphaea from colonia Dacica Sarmizegetusa. In: R. Ardevan-C. Ciongradi-C. Găzdac-L. Ruscu (ed.): Orbis Antiquus. Studia in honorem Ioannis Pisonis. Cluj-Napoca 2004, 470-501.

$=$ Al. Diaconescu-E. Bota: Introduction. Analyse architectonique de l'édifice e la décoration architecturale. In: Al. Diaconescu-E. Bota (ed.): Le Forum de Trajan à Sarmizegetusa. Architecture et sculpture. Cluj-Napoca 2009, 192-211. 
DiACONESCU-PISO 1993

DiEZ 1959

ECK-LOBÜSCHER 2001

EINGARTNER 1992

ÉTIENNE 1958

ÉTIENNE-PISO-DIACONESCU 1994

ÉTIENNE-PISO-DiACONESCU 2004

ÉTIENNE-PISO-DIACONESCU 2006 FIEDLER- HÖPKEN 2010

FIEDLER-HÖPKEN 2013

FISCHER 1996

FISHWICK 1977

FISHWICK 1987

FISHWICK 1991

FISHWICK 2002

FISHWICK 2004

FISHWICK 2005

FITZ 1973

FRANCISCIS 1991

GAYRAUD 1969

GINOUVÈS-MARTIN 1985

GSCHWANTLER 1999

HARL 1989

HÄNLEIN-SCHÄFER 1985

HINRICHS 1974

HOHENHAUSEN 1775

HUMER 2010

HuDECZEK 1977

HUDECZEK 1989

IDR

ILD

JOSEPH HILARIUS 1792-1798

KÁDÁR 1963

KIRÁLY 1886

KIRÁLY 1894
= Al. Diaconescu-I. Piso: Apulum. In: D. Alicu-H. Boegli (ed.): La politique édilitaire dans les provinces de 1'Empire romain. Actes du $1^{\text {er }}$ Colloque Roumano-Suisse, Deva 1991. Cluj-Napoca 1993, 72-73.

= E. DieZ: Flavia Solva. Die römischen Steindenkmäler auf Schloss Seggau bei Leibnitz. Wien 1959.

= W. EcK-Th. LoBÜSCHER: Ein neuer Stadtplan der colonia Ulpia Traiana Dacica Sarmizegetusa. ZPE 137 (2001) 263-269.

= J. EINGARTNER: Fora, Capitolia und Heilichtümer im westlichen Nordafrika. Die römische Stadt (1992) 213-242.

= R. Étienne: Le culte impérial dans la Péninsule Ibérique d'Auguste à Dioclétien. Paris 1958.

= R. Étienne-I. Piso-Al. Diaconescu: Le forum en bois de Sarmizegetusa (Roumaine). Comptes Rendus de l'Accademie des Inscriptions et Belles-Lettres. Paris 1994, 147-164.

= R. Étienne-I. PISO-Al. DiAconescu: Le fouilles du forum vetus de Sarmizegetusa. Rapport general. ActaMN 39-40/1 (2004) 59-154.

= R. Étienne-I. Piso-Al. Diaconescu: Le Forum Vetus de Sarmizegetusa. Bucureşti 2006.

= M. FIEDLER-C. HöPKEN: Micul templu al marilor divinităţi: sanctuarul lui Domnus şi Domna din Sarmizegetusa [The small temple to the great divinities: the sanctuary of Domnus et Domna in Sarmizegetusa]. In: V. Rusu-Bolidenţ-T. Sălăgean-R. Varga (ed.): Studia Archaeologica et Historica. In honorem Magistri Dorin Alicu. Cluj-Napoca 2010, 327-341.

$=$ M. FIEDLER-C. HöPKEN: Rituelle Deponierungen im Domnus und Domna-Heiligtum von Sarmizegetusa (Dakien). In: A. Schäfer-M. Witteye (Hrsg.): Rituelle Deponierungen in Heiligtümer der hellenistisch-römischen Welt. Mainz 2013, 199-214.

= G. FISCHER: Das römische Pola. Eine archäologische Stadtgeschichte. Bayerische Akademie der Wissenschaften, Phil.hist.Klasse 10. München 1996.

= D. Fishwick: The provincial centre at Camulodunum: Towards a historical context. Britannia 28 (1977) 31-50

= D. Fishwick: The Imperial Cult in the Latin West. I. Leiden 1987.

= D. Fishwick: The Imperial Cult in the Latin West. II. Leiden 1991.

= D. FISHwick: The Imperial Cult in the Latin West. III/1-2. Leiden 2002.

= D. FISHwick: The Imperial Cult in the Latin West. III/3. Leiden 2004.

= D. Fishwick: The Imperial Cult in the Latin West. III/4. Leiden 2005.

= J. Fitz: Gorsium-Herculia-Tác. Kecskemét 1973.

= A. De Franciscis: Il sacello degli Augustali a Miseno. Napoli 1991.

= M. GAYRAUD: Temple municipal et temple provincial du culte imperial à Narbonne. Rivista di Studi Liguri 35 (1969) 304-316.

= R. GinOUVÈs-R. MARTIN: Dictionaire méthodique de l'architecture greque et romaine. Publications de l'École Française de Rome 84. Athena-Roma 1985.

= K. Gschwantler: Die Poseidonstatuette von Typus Lateran aus Ephessos. In: E. Freisinger-F. Krinzinger (Hrsg.): 100 Jahre österreichische Forschungen in Ephesos. Akten des Symposions Wien 1995. Wien 1999, 545-548.

= O. HARL: Der Stadtplan von Virunum nach Luftaufnahmen und Grabungsberichten. JRGZM (1989) 521-598.

= H. HÄNLEIN-SCHÄFER: Veneratio Augusti. Eine Studie zu den Tempeln des ersten römischen Kaisers. Roma 1985.

= F. T. HinRICHS: Geschichte der gromatischen Institutionen. Wiesbaden 1974.

= S. J. Hohenhausen: Die Alterthümer Daciens im heutigen Siebenbürgen. Aus den Zeiten, als dieses schöne Land die Römer regierten. Wien 1775.

= F. Humer (Hrsg.): Von Kaisern und Bürgern. Antike Kostbarkeiten aus Carnuntum. Archäologischer Park Carnuntum 2010.

= E. HudeCZEK: Flavia Solva. Berlin-New York 1977.

= E. HudeCZEK: Flavia Solva. Flavia Solva 3 (1989) 39-40.

= I. I. Rusu, et al. (ed.): Inscripţiile Daciei romane [Inscriptions of Roman Dacia]. Bucureşti-Paris 1975-.

= C. Petolescu: Inscripţii latine din Dacia [Latin Inscriptions in Dacia]. Bucureşti, 2005.

= E.-J. Joseph HilariUs: Doctrine nummorum veterum. Vol I-VIII. Wien 1792-1798.

= Z. KÁDÁR: A pannóniai Roma-kultusz történetéhez (Az aquincumi ún. Venus Victrix ikonográfiai és történeti problémái) (Contribution à l'histoire du culte de la déesse Roma en Pannonié. Les problèmes historiques et iconographiques de «Venus Victrix» du musée á Aquincum). BudRég 20 (1963) 71-83.

= P. KIRÁLY: A sarmizegetusai mithraeum [Mithraeum in Sarmizegetusa]. Budapest 1886.

= P. KIRÁLY: Dacia Provincia Augusti. II. Nagybecskerek 1894. 
KUN 1886

KuUN-TORMA-TÉGLÁS 1902

LACHMANN-BLUHME-RUDORFFMOMMSEN 1852

LEÓN 1988

LETZNER 1990

LORENZ 1987

MANSEL 1975

Mar-Ruiz DE Arbulo-VIVÓ 2010

MAR-Ruiz de ARbulo-VIVó 2011

MAR-RUIZ DE ARBULO-VIVÓ 2014

MARCU-CUPCEA 2011

MARSIGLi 1726

MăRghitan-Petloescu 1974

MĂRghitAN-PEtLOESCU 1976

MELLOR 1981

MrÁV 1998

MuRILLO 2010

NASH 1961-1962

NEMETI 2005

NEMETI 2012

NEMETI 2015

NEUOKOM-RADTKE 1997

NiESSEN 1906-1910

PaUlovics 1940

PAUlOVICS 1943

PISO 1983

PISO 1993

PISO 1998

PISO 2005

PISO 2013

PISO-RUSU 1977

PISO-DiACONESCU 1985-1986

Piso-Diaconescu 1999

Piso-Ţentea 2011

Piso-Marcu-Tentea-CuPCEA-
= R. Kun: A társulat 1883. évi junius hó 1-től 1884. évi deczember hó 31-ig kifejtett müködésének vázlata [Summary of the Activities of the Association between 1. June 1883 and 31 December 1884]. Hunyadvármegyei Történelmi és Régészeti Társulat Évkönyve 3 (1886) 82-99.

= G. KUUN-Zs. TORMA-G. TÉGLÁs: Hunyadvármegye földjének története az őskortól a honfoglalásig [The history of Hunedoara County from Prehistory until the Hungarian Conquest]. Budapest 1902.

= K. Lachmann-Fr. Bluhme-A. A. Fr. RudorfF-Th. Mommsen (ed.): Gromaticii veteres. Corpus agrimensorum Romanorum. Berlin 1852.

= P. LEÓN: Traianaeum de Italica. Sevilla 1988.

= W. LETZNER: Römische Brunnen und Nymphaea in der westlichen Reichshälfte. Münster 1990.

= T. LoRENZ: Römische Städte. Dormstadt 1987.

= A. M. Mansel: Die Nymphaeen von Perge. IstMitt 25 (1975) 367-372.

= R. Mar-J. Ruiz de Arbulo-D. Vivó: El foro de Tarraco entre la República y el Imperio. In: R. Y. Gonzalez-Villaescusa-J. Ruiz de Arbulo (ed.): Simulacra Romae II (Reims, nov. 2008). BSAChamp 19. Reims 2010, 39-70.

= R. MaR-J. Ruiz de Arbulo-D. Vivó: Las tres fases constructivas del Capitolio de Tarragona. In: J. Lopez-O. Martin (ed.) Actes del Congres Internacional en Homenatge a Th. Hauschild, Tarragona 2009. Butlletí Arqueológic 31-32 (2011) 507-540.

= R. Mar-J. Ruiz de Arbulo-D. Vivó: El capitolio de Tarraco. In: I. Piso-R. Varga (Hrsg.): Trajan und seine Städte. Cluj-Napoca 2014, 37-68.

= F. MARCU-G. CupCEA: The topography of Colonia Ulpia Traiana Augusta Dacica Sarmizegetusa and the first centuriation in Dacia. AKorr 41 (2011) 543-560.

= L. F. MArsigLi: Dannubius Pannonico-Mysicus. Observationibus geographicis, astronomicis, hydrographicis, historicis, physicis perlustratus et in sex tomos digestus. II: Hague. Amsterdam 1726.

= L. Mărghitan-C. C. Petolescu: Vota pro salute principis. StudClas 16 (1974) 245-247.

= L. Mărghitan-C. C. Petolescu: Vota pro salute imperatoris in an inscription at Ulpia Traiana Sarmizegetusa. JRS 66 (1976) 84-86.

= R. MELLOR: The Godess Roma. ANRW II 17:2. Berlin-New York 1981, 1002-1004.

= Zs. MRÁv: Architrvávfelirat Savariából, a város nevének említésével (Eine Architrav-Inschrift mit erwähnung des Stadtnamens aus Savarien). Savaria 23/3 (1998) 217-236.

= J. F. MuriLlo: Colonia Patricia Corduba hasta la dinastía flavia. Imagen urbana de una capital provincial. In: R. G. Villaescusa - J. Ruiz de Arbulo (éd.): Simulcra Romae. II: Rome, les capitales de province (capita prouinciarum) et la création d'un espace commun européen. Une approche archéologique. Actes du Colloque tenu à Reims, les 19, 20 et 21 novembre 2008. BSAChamp Mémoire 19. Reims 2010, 71-93.

= E. NAsh: Bildlexikon zur Topographie des antike Rom. I-II. Tübingen 1961-1962.

= S. NEMETI: Sincretismul religios în Dacia romană [Religious Syncretism in Roman Dacia]. ClujNapoca 2005.

= S. NEMETI: Dialoguri păgâne. Formule votive şi limbaj figurat în Dacia romană [Pagan Dialogues. Votive Formulae and Figurative Language in Roman Dacia]. Iaşi 2012.

= S. Nemeti: Vota pro salute imperatoris in Dacia. Classica et Christiana 10 (2015) 251-262.

= C. NeuOKOM-RADTKE: Stätten von Glauben und Verehrung - Tempel und Heiligtümer. In: ZsidIFURGER 1997, 114

= H. NIESSEN: Orientation. Studien zur Geschichte der Religion. Berlin 1906-1910.

= I. PAulovics: Savaria Capitoliuma (Il Capitolium di Savaria). ArchÉrt 3.ser. 1 (1940) 19-47.

= I. PAulovics: Savaria-Szombathely topográfiája [The Topography of Savaria-Szombathely]. Szombathely 1943.

= I. PISO: Inschriften von Prokuratoren aus Sarmizegetusa. 1. ZPE 50 (1983) 233-251.

= I. Piso: Fasti Provincae Daciae. I. Bonn 1993.

= I. PISO: Inschriften von Prokuratoren aus Sarmizegetusa. 2. ZPE 120 (1998) 253-271.

= I. PISO: An der Nordgrenze des Römischen Reiches. Stuttgart 2005.

= I. PISO: Fasti Provinciae Daciae. II. Bonn 2013.

= I. PISO-A. RUSU: Un relief din Sarmizegetusa cu reprezentarea lui Silvanus şi a nouă Silvane [Un relief de Sarmisegatusa représentant Silvanus et neuf Silvanes). ActaMN 14 (1977) 155-158.

= I. PISO-Al. Diaconescu: Forurile din Ulpia Traiana Sarmizegetusa (Les fora de Ulpia Traiana Sarmizegetusa). ActaMN 22-23 (1985-1986) 161-183.

= I. PISO-Al. DiACONESCU: Testo epigrafico, support architettonico e contest archeologico nei fori di Sarmizegetusa. XI Congresso Internazionale di Epigrafia Greca e Latina, Roma 18-24 settembre 1997, Roma 1999, 125-137.

= I. Piso-O. ŢENTEA: Un nouveaue temple palmyrénien à Sarmizegetusa. Dacia 55 (2011) 1-18. 
VARGA 2012

PócZY 1980

PóCZY 2004

RAKOB 1979

RICIS

Ruiz DE ARBULO-Vivó-MaR 2006

Rusu-Pescaru-Alicu 2000

SALOM I GARRETA 2006

SANCTIS 2007

SCHÄFER 2007

SCHWARTZER 2002

SoSZTARITS 1994

SÜSSENBACH 1989

SZABÓ 2004

SZABÓ 2007

SZABÓ 2014

SZINTE 1897

TED'A 1989

TÉGLÁS 1890

TÉGLÁS 1906

TÉGLÁS 1907

TÉGLÁS 1914

TóTH 1971

TóTH 1973

TÓтH 2001

Н. То́тH 2005

I. Tóth 1998

TRUNK 1991

Vitruvius 1964

ZSIDI-FURGER 1997
= I. Piso-F. Marcu-O. ŢenteA-G. CupceA-R. VArga: Das Kapitol von Sarmizegetusa. Dacia 56 (2012) 119-124.

= K. PóczY: Szent kerületek Aquincum és Brigetio aqueductusánál (Sanctuaires près des aqueducs d'Aquincum et de Brigetio). ArchÉrt 107 (1980) 3-29.

= K. PócZY: Aquincum. Budapest római kori történelmi városmagja [Aquincum. Historic Centre of Budapest in the Roman Period]. Budapest 2004.

= Fr. RAKOB: Das Groma-Nymphaeum im Legionslager von Lambesis. RömMitt 86 (1979) 375.

= L. BriCAUlT: Recuil des Inscriptions Concernant les Cultes Isiaques. Mémoires de l'Académie des Inscriptions et les Belles-Lettres 31. Paris 2005.

= J. Ruiz De Arbulo-D. Vivó-R. MAR: El capitolio de Tarraco. Identificación y primeras observaciones. In: D. Vaqerizo-J. F. Murillo (ed.): El concepto de lo provincial en el mundo antiguo. Homenaje a la Prof. Pilar León, Córdoba. 1. Córdoba 2006, 391-418.

= A. Rusu-Pescaru-D. Alicu: Templele romane din Dacia. Deva 2000.

= C. SAlom i Garreta: El Auguraculum de la colonia Tárraco. Archivo Español de Arqueología 79 (2006) 69-87.

= G. DE SANCTIS: Solco, muro, pomerio. MEFRA 119/2 (2007) 503-526.

= A. SCHÄFER: Tempel und Kult in Sarmizegetusa. Ein untersuchung zur Formierung religiöser Gemeinschaften in der Metropolis Dakiens. Köln 2007.

= W. SchwARTZER: Vereinslokale im hellenistischen und römischen Pergamon. In: U. EgelhaafGaiser-A. Schäfer (Hrsg.): Religiöse Vereine in der römischen Antike. Untersuchungen zu Organisation, Ritual und Raumordnung. Tübingen 2002, 221-259.

= O. SoszTARITs: Topographische Forschungen im südlichen Teil von Savaria. In: Gy. Hajnóczy (ed.): La Pannonia e l'Imperio Romano. Roma 1994, 233-241.

$=$ U. SüsSENBACH: Der Reichsaltar der Roma und des Augustus in Lugdunum. Ein barbarisierter als mit dem Bild Neros und das Problem der nachaugusteischen Altarserien. BJ 189 (1989) 73-96.

= Á. Szabó: L. F. Marsigli és Sarmizegetusa topográfiája. A provinciális forum és az Ara Augusti Daciában (L. F. Marsigli und die Topographie von Sarmisegetusa. Das Forum provinciale und die Ara Augusti in Dacia). ArchÉrt 129 (2004) 83-119

= Á. Szabó: Dáciai papság (I sacerdozi nella Dacia). Budapest 2007.

= Cs. Szabó: Urbs et cultus deorum. Római vallás a Kr.u. II.-III. századi városokban: módszertani áttekintés. [Roman religion in the $2^{\text {nd }}-3^{\text {rd }} \mathrm{c}$. AD cities. A methodological review]. Vallástudományi Szemle 2014/1-2 (2014) 41-58.

= G. SzINTE: Ulpia Traiana, ezelőtt Sarmizegethusa, ma Várhely amphiteatruma [The amphiteather in Ulpia Traiana, prevoiusly Sarmizegetusa, nowadays Várhely]. Hunyadvármegyei Történelmi és Régészeti Társulat Évkönyve 8 (1897) 35-37.

= TED'A ( = Taller Escola d'Arqueologia de Tarragona): El Foro provincial de Tárraco, un complejo arquitectónico de época flavia. Archivo Español de Arqueología 62 (1989) 141-191.

= G. TÉGLÁs: Iupiter és Iuno szoborcsoportról [About the group of figures with Jupiter and Juno]. ArchÉrt 10/4 (1890) 360-362.

= G. TÉGLÁs: A várhelyi syrus templom (Temple sacré aux syriennes à Várhely, Sarmisegetusa). ArchÉrt 26 (1906) 321-330.

G. TÉGLÁs: Újabb adalék a sarmizegetusai alvilági cultus történetéhez (Donnée nouvelle servant l'histoire des cultes chtoniques à Sarmisegetusa en Dacie). ArchÉrt 27/4 (1907) 368-370.

= G. TÉGLÁs: Caelestis Virgo jelentősége Dáciában [About the significance of Caelestis Virgo in Dacia]. ArchÉrt 34/4 (1914) 350-354.

= E. То́тн: A savariai insularendszer rekonstrukciója (Rekonstruktion des Insula-Systems in Savaria). ArchÉrt 98 (1971) 143-169.

= E. Tóтн: A savariai capitoliumi triász torzóinak kérdése (Die Problematik der capitolinischen TriasTorsos von Savaria). ArchÉrt 100 (1973) 19-31.

= Е. То́тн: A császárkultusz főoltára Pannonia Superiorban (Ara Augustorum in Pannonia Superior). ArchÉrt 126 (2001) 5-33.

= Н. То́тн: Megjegyzések a savariai Iseum dombormüveinek kérdéséhez (Bemerkungen zur Frage der Reliefs des Isis Heiligtums in Savaria). Savaria 29 (2005) 233-252.

= I. Tо́тH: A savariai Iseum kutatásának eredményei és feladatai (Ergebnisse und Aufgaben der Erforschung des Iseums von Savaria). Savaria 23/3 (1998) 329-336.

= M. TRUnK: Römische Tempel in den Rhein- und westlichen Donauprovinzen. Augst 1991.

= Vitruvius: Despre arhitectură [De architectura. Ten Books on Architecture]. Bucureşti 1964.

= P. ZSIDI-A. R. Furger (eds): Out of Rome. Augusta Raurica/Aquincum = Das Leben in zwei römischen Provinzstädten = Élet a Római Birodalom két városában. Basel 1997. 